\title{
Moet de strafrechter ook de scheidsrechter zijn van het publieke debat?
}

\author{
De scheiding der machten in het licht van de vrijheid van \\ meningsuiting voor volksvertegenwoordigers
}

Jip Stam

\section{Inleiding}

Op 12 februari van dit jaar gebeurde er in Den Haag iets bijzonders. Na lang aandringen stemde een meerderheid van de Tweede Kamer in met het voorstel van parlementariër Geert Wilders tot het houden van een debat over de lopende strafprocedure tegen hem. Wilders hoopte daarmee 'een politiek oordeel' van de Kamer te krijgen over de vermeende politieke inmenging door het Ministerie van Justitie en Veiligheid bij de totstandkoming en invulling van de tegen hem in 2014 ingestelde vervolging. Daarvoor waren in de maanden voorafgaand aan zijn verzoek verschillende aanwijzingen naar boven gekomen, zoals e-mailwisselingen tussen ambtenaren over de juridische strategie van het Openbaar Ministerie en stukken waaruit zou blijken dat de vervolgbaarheid van Wilders slechts enkele dagen na zijn 'Minder Marokkanen'-uitspraak op de agenda van de ministerraad heeft gestaan. ${ }^{1}$ Reden genoeg voor de Tweede Kamer om haar gebruikelijke staatsrechtelijke beleefdheid jegens de rechterlijke macht ${ }^{2}$ tijdelijk te laten varen en de zaak-Wilders nog vóór de uitspraak van het gerechtshof met verantwoordelijk minister Grapperhaus te bespreken. ${ }^{3}$

Vanuit constitutioneel oogpunt was dat een begrijpelijke beslissing, nu de regering mogelijk buiten haar staatsrechtelijke bevoegdheid is getreden en daarmee mogelijk het principe van de machtenscheiding heeft geschonden. Tegelijkertijd rijst de vraag of de Tweede Kamer haar pijlen wel op de juiste staatsmacht heeft gericht. De Hoge Raad heeft namelijk sinds de aanvang van het tweede Wilders-proces in 2014 ook niet stil gezeten. In een tweetal arresten (uit 2014 en 2018) heeft de hoogste rechter zich specifiek over de bijzondere status van politici in het publieke debat uitgelaten. ${ }^{4}$ In deze nieuwe jurisprudentie over

1 K. Versteegh, 'Bemoeide justitie zich met de vervolging van Wilders?' NRC.nl, 4 februari 2020.

2 Voor een interessante bespiegeling over dit punt, zie W. Voermans, 'Parlementariërs en de rechter', in Kringen in de hofvijver: liber amicorum Joop van den Berg, red. P. Bootsma, B. Van den Braak \& L. Verhey (Maastricht: Interfax 2012), 240-249.

3 Dit artikel is geschreven vóór de uitspraak van het hof op 4 september 2020 (ECLI:NL:GHDHA: 2020:1606). De auteur heeft kennis genomen van die uitspraak en is tot de conclusie gekomen dat dit aan de algemene strekking van zijn argumentatie niet afdoet. Daarom is besloten het artikel in zijn oorspronkelijke vorm te publiceren. Voor een korte opmerking over de uitspraak van het hof, zie voetnoot 92.

4 HR 16 december 2014, ELCI:NL:HR:2014:3583; HR 10 april 2018, ECLI:NL:HR:2018:539. 
de toepassing van de artikelen 137c en 137d Sr - de delicten waarvoor Wilders zich moet verantwoorden - dicht de Hoge Raad politici een 'bijzondere verantwoordelijkheid' toe om zich te onthouden van uitlatingen die 'strijdig zijn met de wet en de grondbeginselen van de democratische rechtsstaat'. Dit houdt in dat de strafrechter bij het toepassen van de desbetreffende delicten niet slechts heeft te toetsen of uitlatingen beledigend zijn of aanzetten tot discriminatie, haat of geweld, maar ook - wanneer het gaat om uitlatingen van een politicus - of deze 'aanzetten tot onverdraagzaamheid'. ${ }^{5}$ Omdat de Hoge Raad daarmee suggereert dat aan politici strengere eisen moeten worden gesteld met betrekking tot de uitoefening van het recht op vrijheid van meningsuiting, kan dit nieuwe criterium de uitkomst van de zaak-Wilders (en vergelijkbare procedures in de toekomst) danig beïnvloeden.

Om die reden ligt het voor de hand om de jurisprudentie van de Hoge Raad en de wetgeving waarop zij betrekking heeft, kritisch tegen het licht te houden. Twee kwesties verdienen daarbij in het bijzonder de aandacht. Ten eerste kan worden betwijfeld of de rechtszekerheid van deelnemers aan politieke debatten nog wel valt te waarborgen gelet op de steeds complexer wordende jurisprudentie rondom de artikelen 137c en 137d Sr. Voorts rijst de vraag hoeveel invloed de rechter als gevolg van die complexiteit kan uitoefenen op het toepassingsbereik van deze delicten. Als we moeten constateren dat die invloed aanzienlijk is, dan kan dit betekenen dat de gepaste afstand tussen de politiek en de rechtspraak die in elke democratie noodzakelijk is, in het geding komt. Het gaat dus niet zozeer om de vraag of de rechter zich wel afdoende tegen inmenging van de politiek kan beschermen - hetgeen met betrekking tot de rechterlijke onafhankelijkheid meestal de voornaamste zorg is - maar omgekeerd: of de rechter niet te veel in het vaarwater van de politiek kan geraken. Kortom: komt scheiding tussen de rechterlijke macht en de politiek mogelijk onder druk te staan bij de toepassing van de uitingsdelicten $137 \mathrm{c}$ en $137 \mathrm{~d}$ Sr op uitlatingen van volksvertegenwoordigers? Hoewel er in de bestaande Nederlandse literatuur al aandacht is geweest voor de verhouding tussen volksvertegenwoordigers en de vrijheid van meningsuiting, ${ }^{6}$ is er vanuit rechtstheoretisch perspectief nog betrekkelijk weinig bij dit specifieke vraagstuk stilgestaan. In dit artikel zal een poging worden gedaan dit gat te dichten.

Daartoe zal allereerst de samenhang tussen de vrijheid van meningsuiting en de representatieve democratie worden onderzocht aan de hand van enkele rechtstheoretische gezichtspunten (paragraaf 2 ). Hieruit zal naar voren komen

$5 \quad$ HR 16 december 2014, ELCI:NL:HR:2014:3583, par. 4.4.4.

6 Zie bijvoorbeeld Th. Rosier, 'Is de vrijheid van meningsuiting een grondrecht?', NJLP (1997), 9-27; A.J. Nieuwenhuis, 'Tussen grondrechtelijke vrijheid en parlementaire onschendbaarheid: de vrijheid van meningsuiting van de parlementariër', TvCR afl. 1 (2010), 4-23; R. Nehmelman, 'Spreken is zilver, maar wie bepaalt wanneer zwijgen goud is', Ars Aequi afl. 5 (2011), 355-360; R. Nehmelman, 'Uitbreiding van de parlementaire immuniteit', in Mag ik dit zeggen: beschouwingen over de vrijheid van meningsuiting, red. A. Ellian, G. Molier \& T. Zwart (red.), (Den Haag: Boom Juridisch 2013), 243-262; P.B. Cliteur \& A. Ellian, De staat versus Wilders (Den Haag: Boom Juridisch, 2019). 
dat de vrijheid van meningsuiting een zeker constitutioneel primaat geniet in elke democratie en dat dit primaat in verband kan worden gebracht met de parlementaire immuniteit; een grondwettelijke regeling die deelnemers aan het parlementaire debat volledig vrijwaart van strafrechtelijke vervolging. Voorts zal het 'gewone' recht op vrije meningsuiting, dat buiten de sfeer van het parlement toepasselijk is, worden besproken, met bijzondere aandacht voor de inhoud en toepassing van de artikelen 137c en 137d Sr (paragraaf 3). Daaruit zal blijken dat zowel de formulering als de toepassing van deze delicten op gespannen voet kan staan met het legaliteitsbeginsel, hetgeen voor zowel de rechtszekerheid als de scheiding tussen de politiek en de rechter niet bevorderlijk is. Voorts zal worden bezien in hoeverre de Hoge Raad deze zorg kan wegnemen op basis van zijn contextuele toetsingsmodel voor de artikelen 137c en 137d Sr (paragraaf 4). Het zal blijken dat, hoewel dit toetsingsmodel extra bescherming kan bieden aan politici die zich mengen in een politiek-maatschappelijk debat, deze bescherming op losse schroeven is komen te staan als gevolg van het nieuwe, door de Hoge Raad geformuleerde onverdraagzaamheidscriterium. Tot slot zal in de conclusie een samenvatting worden gegeven van de bevindingen en wordt getracht enkele oplossingen aan te dragen die voor het vrije politieke debat en de scheiding der machten bevorderlijk kunnen zijn.

\section{De vrijheid van meningsuiting: grondslag van de democratie}

Alvorens de rol van de rechter bij de afbakening van de vrijheid van meningsuiting te kunnen evalueren, dient eerst te worden verhelderd wat deze vrijheid eigenlijk betekent voor de representatieve democratie. Daarbij zijn uiteraard talloze perspectieven te kiezen met elk hun eigen uitgangspunten en accenten, maar met het oog op de beperkte omvang van dit artikel en de specifieke constitutionele en strafrechtelijke problematiek die hier centraal staat, zullen slechts drie perspectieven worden uitgelicht. Eerst zullen enkele liberale verdedigingen van de vrijheid van meningsuiting worden besproken, om deze vervolgens af te zetten tegen de democratische verdediging van Eric Heinze. Ik zal betogen dat de laatstgenoemde benadering, waarbinnen de mogelijkheid tot deelname aan het publieke debat niet als een individueel recht maar als de legitimerende voorwaarde van de democratie wordt gekenschetst, de beste papieren heeft. Bovendien sluit het aan op een belangrijk principe in de Grondwet, namelijk de parlementaire immuniteit. Deze staatsrechtelijke norm kan, zoals in paragraaf 2.2 zal worden uiteengezet, niet alleen worden gezien als de ruggengraat van het vrije publieke debat maar is tevens een waarborg voor de in de democratische rechtsstaat noodzakelijke scheiding tussen de politiek en de rechtspraak. Als zodanig is het van betekenis voor het centrale vraagstuk in dit artikel. 


\subsection{Vrijheid van meningsuiting en democratisch burgerschap}

Wie zoekt naar een rechtvaardiging voor de vrijheid van meningsuiting kan zoals gezegd bij veel auteurs terecht. ${ }^{7}$ De Britse filosoof John Stuart Mill kan daarbij in elk geval niet ontbreken. In zijn beroemde essay On Liberty (1859) presenteerde de liberale denker een verdediging van het vrije woord die vooral bekend is van de stelling dat elke mening, hoe onwaar of verwerpelijk die ook lijkt, een deel van de waarheid kan bevatten. Mill was er dan ook van overtuigd dat een vermoeden nooit kan uitgroeien tot een 'oprechte en hartgrondige overtuiging' als het niet eerst aan felle kritiek wordt blootgesteld. ${ }^{8}$ Het verbieden van een bijdrage aan de publieke discussie kan daarom schadelijk zijn voor de ontwikkeling van zowel het individu als de maatschappij als geheel, nu een dergelijk ingrijpen de zoektocht naar waarheid belemmert. De staat zal daarom in beginsel alle meningsuitingen moeten toestaan, met als enige uitzondering de gevallen waarbij aantoonbare schade (harm) aan anderen wordt toegebracht. ${ }^{9}$ Slechts dan moet het recht op vrijheid van meningsuiting wat Mill betreft wijken. Deze theorie raakt aan een belangrijke kern van de democratie, namelijk de onvolkomenheid en feilbaarheid van individuele standpunten. Om tot geïnformeerde, weloverwogen politieke beslissingen te kunnen komen, moeten die standpunten vrij met elkaar kunnen botsen. Alleen zo kan een samenleving goede collectieve beslissingen nemen.

Volgens Ronald Dworkin is deze benadering ietwat te consequentialistisch, omdat zij primair gericht is op de instrumentele functie van de vrijheid van meningsuiting. Dworkin stelt er daarom een meer principiële rechtvaardiging van de uitingsvrijheid tegenover, gebaseerd op de universele norm van 'menselijke waardigheid'. ${ }^{10}$ Toegespitst op de democratie houdt deze norm in dat geen enkele collectieve (meerderheids)beslissing genomen mag worden zonder dat elk individu dat daaraan wordt onderworpen daarover zijn bezwaren kan uiten:

'Fair democracy requires that each citizen have not just a vote but a voice: a majority decision is not fair unless everyone has had a fair opportunity to express his or her attitudes or opinions or fears or tastes [...], not just in the hope of influencing others (though that hope is crucially important), but also just to confirm his or her standing as a responsible agent in, rather than a passive victim of, collective action. ${ }^{11}$

De rechtvaardiging van de vrijheid van meningsuiting is wat Dworkin betreft dus gelegen in het belang van ieder individu om gehoord te worden. Dit geldt ook - en misschien wel juist - voor racisten en mensen die er anderszins controversiële

7 Voor een beknopt overzicht, zie A.J. Nieuwenhuis, Over de grens van de vrijheid van meningsuiting, (Nijmegen: Ars Aequi Libri, 2015), 21 e.v.

8 J.S. Mill, Over vrijheid (Amsterdam: Boom 1996 [1859]), 98.

9 Mill, Over vrijheid,(1996) 43. Zie ook Nieuwenhuis, Over de grens van de vrijheid van meningsuiting (2015), 27-28.

10 R. Dworkin, 'Foreword', in Extreme speech and democracy, red. I. Hare \& J. Weinstein (Oxford: Oxford University Press, 2009), vii.

11 Dworkin, 'Foreword' (2009), vii. 
opvattingen op na houden. Immers, als we deze mensen zouden verbieden dergelijke opvattingen met de samenleving te delen, dan ontnemen we onszelf het recht om die mensen te laten buigen voor wetgeving en beleid waar zij op tegen zijn: "If we intervene too soon in the process through which collective opinion is formed, we spoil the only democratic justification we have for insisting that everyone obey these laws'. ${ }^{12}$

Hoewel Dworkin inderdaad een principieel verband schetst tussen de vrijheid van meningsuiting en de legitimiteit van collectieve beslissingen, is het maar de vraag of het hier om een 'democratische rechtvaardiging' gaat. De vrijheid van meningsuiting wordt door Dworkin namelijk begrepen vanuit haar betekenis voor het individu en specifieker voor diens menselijke waardigheid. Zijn stelling dat de vrijheid van meningsuiting ook los van de democratie zou moeten gelden als een universeel mensenrecht is daarvan het bewijs. ${ }^{13}$ Een logische gevolgtrekking is dan ook dat het niet zoveel uitmaakt of de staat op democratische wijze wordt bestuurd of niet, zolang er maar de mogelijkheid bestaat voor iedere burger om protest aan te tekenen tegen politieke besluiten. Weliswaar suggereert Dworkin dat een democratie daarvoor een meer geschikte staatsvorm is dan een staat die wordt bestuurd door 'prophets or generals', maar dit onderscheid lijkt voor het principe dat hij verdedigt niet van wezenlijk belang te zijn. Waar het Dworkin uiteindelijk om gaat, is de norm van gelijke behandeling (equal concern): het basale mensenrecht waar de meer gedetailleerde mensenrechten, zoals de vrijheid van meningsuiting, uit voortvloeien. ${ }^{14}$ Het recht op vrijheid van meningsuiting en de 'fair democracy' die zij mogelijk maakt, is dus slechts een afgeleide van het hogere ideaal van gelijke behandeling. Een ideaal dat Dworkin kennelijk zo hoog acht dat het zelfs niet mag wijken voor de - eveneens uit dit principe voortkomende wens om beledigende of discrimineerde opmerkingen uit het publieke debat te weren.

Volgens Eric Heinze doet Dworkin een dappere poging om het recht op vrije meningsuiting met de democratie te verbinden, maar slaagt hij daar niet in. Door gelijke behandeling als allerhoogste norm aan te slaan, en de vrijheid van meningsuiting slechts als een afgeleide daarvan te beschouwen, legitimeert hij niet zozeer de democratie maar eerder de staat in algemenere zin. Gelijke behandeling is namelijk, zo stelt Heinze, niet het onderscheidende kenmerk van democratie. Weliswaar is het van groot belang voor een democratie, maar is het niet een onderscheidende eigenschap ervan. Wat een democratie daarentegen wel onderscheidt van andere staatsvormen is het feit dat elk van zijn burgers kan stemmen (vote) en daarbij zijn stem mag laten horen (voice). Het gaat daarbij specifiek om de mogelijkheid van burgers om een eigen standpunt in te nemen in de openbare discussie, zonder dat zij berispt kunnen worden vanwege de inhoud van hun standpunt. Dit is een specifieke, legitimerende voorwaarde van de democratie, in tegenstelling tot het recht op gelijke behandeling dat eerder een 
legitimerende voorwaarde is van de rechtsstaat. ${ }^{15}$ Heinze stelt Dworkin daarom voor een keuze. Wil hij de vrijheid van meningsuiting rechtvaardigen op democratische gronden dan zal hij deze vrijheid niet langer als (de afgeleide van) een universeel mensenrecht moeten definiëren maar als een voor de democratie onderscheidend burgerlijk recht. ${ }^{16}$ Vrijheid van meningsuiting moet, om het anders te formuleren, niet alleen als een liberaal recht worden opgevat (gericht op de autonomie en waardigheid van het individu) maar tevens en in de eerste plaats als een democratisch principe (gericht op de uitoefening van democratisch burgerschap). ${ }^{17}$

Op basis van dit onderscheid maakt Heinze inzichtelijk dat de vrijheid van iedere burger om zich te mengen in de politiek-maatschappelijke discussie niet als een van de vele onderdelen van de democratische constitutie moet worden opgevat maar als 'de constitutie van de democratische constitutie'. ${ }^{18}$

'A formalized voting procedure is not the origin, but already the product of an ever self-renewing public discourse, which, as constitutive of such institutional arrangements, can also always move to change them. Vote ensues from voice [...]. Voting derives, then, from the more fundamental citizen prerogative of expression within public discourse. ${ }^{19}$

Deze meer fundamentele, pre-constitutionele status van het publieke debat vereist beslist geen onbegrensde vrijheid (free speech absolutism), maar in elk geval wel dat iedere burger vrije toegang heeft tot de publieke discussie en daarbij niet beperkt wordt in het uiten van standpunten (viewpoint absolutism) ${ }^{20}$ Dit betekent dat de overheid bepaalde inhoud (content) die aantoonbaar schadelijk is, zoals het aanzetten tot geweld of het openbaar maken van staatsgeheimen, mag verbieden, maar zij mag niet, zodra de discussie over een bepaalde inhoud eenmaal is toegestaan, standpunten (viewpoints) over die inhoud uit het publieke debat weren. ${ }^{21}$ Dit geldt wat Heinze betreft ook voor hate speech (de verzamelterm voor groepsbelediging en het aanzetten tot haat of discriminatie). Zolang bijvoorbeeld het onderwerp 'toelating en integratie van vreemdelingen' inhoudelijk is

18 Heinze, Hate speech and democratic citizenship (2016), 82. Zie ook E. Heinze, 'Een antiliberale verdediging van de vrijheid van meningsuiting: grondslagen van de democratie in de westerse filosofische canon', in De grenzen van het publieke debat, red. T. Herrenberg (Den Haag: Boom Juridisch, 2019), 133; E. Heinze, 'The constitution of the constitution: Democratic Legitimacy and Public Discourse', in Rancière and the possibility of law, red. J. Extabe \& M. Lopez (red.), (Abingdon: Roudlegde, 2018), 111-128.

19 Heinze, Hate speech and democratic citizenship (2016), 49.

20 Heinze pleit met andere woorden niet voor 'free speech absolutism' maar voor 'viewpoint absolutism'. Voor een toelichting zie Heinze 2016, 77.

21 Heinze, Hate speech and democratic citizenship (2016), 82; Heinze, 'Een antiliberale verdediging van de vrijheid van meningsuiting: grondslagen van de democratie in de westerse filosofische canon' (2019), 131. 
toegestaan, dan mogen publieke uitlatingen over dit onderwerp die niet leiden tot aantoonbare schade niet zomaar worden bestraft. De wellicht begrijpelijke wens om uitlatingen die aanzetten tot haat of discriminatie te bestrijden, kan dus niet op democratische gronden prevaleren boven de vrijheid van meningsuiting. ${ }^{22}$ Dit zou immers afdoen aan de legitimiteit van de democratie.

Tegen deze opvatting kan worden ingebracht dat uitingen die weliswaar niet leiden tot haat of discriminatie maar daar wel toe aanzetten, wel degelijk 'schadelijk' (harmful) kunnen zijn voor de reputatie van bepaalde groepen of individuen en daarom uit het publieke debat geweerd moeten kunnen worden. Aldus betoogt Jeremy Waldron in het boek The Harm in Hate Speech (2012), waarin de stelling wordt verdedigd dat strafwetgeving ter bestrijding van hate speech er is 'for the benefit of vulnerable racial, ethnic and religious minorities, to uphold their reputation and their dignity'. ${ }^{23}$ Waldrons opvatting is geënt op het Rawlsiaanse ideaal van een 'well-ordered society', een samenleving waarin ieder lid de menselijke waardigheid en de basale rechten van elk ander lid publiekelijk respecteert. Aangezien uitingen van haat, discriminatie of belediging jegens een bevolkingsgroep niet voldoen aan deze 'widespead acceptance of the fundamentals of justice', mag de staat zulke uitspraken uit de publieke discussie weren. Wie immers de basale gelijkheid en waardigheid van alle mensen niet onvoorwaardelijk wil erkennen, verspeelt zijn recht op deelname aan de (rationale) publieke discussie. ${ }^{24}$

De oplettende lezer zal opmerken dat Waldron zich op dezelfde twee principes beroept als Dworkin, namelijk 'fairness' en 'equality', maar tot een heel andere conclusie komt. Dit heeft te maken met hun uiteenlopende waardering en invulling van het begrip 'menselijke waardigheid'. Dworkin leunt daarbij meer op fairness, waarbij hij de nadruk legt op het recht om gehoord te worden. Waldron daarentegen benadrukt equality, waarbij het recht om met respect bejegend te worden centraal staat. Wat beide opvattingen echter duidelijk gemeen hebben - en dat is hier het meest relevant - is de liberale bril waarmee zij de politieke legitimiteit van de democratie inkleuren. Net als Dworkin gaat Waldron er namelijk vanuit dat een democratie geen democratie mag heten als haar burgers voorstellen willen doorvoeren die in strijd zijn met de autonomie en de waardigheid van het individu. Democratie is namelijk zelf ook een mensenrecht, afgeleid van de hogere norm van 'menselijke waardigheid', en daarom geldt - althans in het geval van Waldron - dat alles wat met deze hogere norm strijdig is ipso facto anti-democratisch moet zijn.

Het is precies deze vereenzelviging van liberalisme en democratie, deze poging om beide begrippen onder een en dezelfde fundamentele norm te scharen, die het

22 Heinze, Hate speech and democratic citizenship (2016), 157, 173-175. Hier duikt ondanks de deontologische inbedding van Heinze's democratiebegrip ook het consequentialistische schadebeginsel van Mill weer op.

23 J. Waldron, The Harm in Hate Speech (Cambridge MA: Harvard University Press, 2012).

24 Waldron, The Harm in Hate Speech (2012), 82-83. 
zicht op de werkelijke grondslag van de democratie belemmert. Deze grondslag ligt namelijk, zoals Heinze terecht stelt, buiten het bereik van het liberalisme en is veeleer verwant aan de klassieke notie van de volkssoevereiniteit. ${ }^{25} \mathrm{Om}$ het nut en de noodzaak van een open en vrije publieke discussie voor de democratie te kunnen aanwijzen, zal men zich dus niet op liberale beginselen moeten oriënteren maar primair op democratische. Doordat met name Waldron dit onderscheid niet onderkent, raakt hij verstrikt in een belangrijke denkfout die Heinze ook wel de legitimacy fallacy noemt. Dit houdt in dat de legitimiteit van de democratie wordt afgemeten aan andere dan democratische principes, zoals universele mensenrechten. Een inbreuk op zo'n universeel mensenrecht, bijvoorbeeld het recht op een eerlijk proces, wordt dan strijdig geacht met (de grondbeginselen van) de democratie, terwijl de schending van dit recht - hoe onwenselijk ook - op zich niets afdoet aan de legitimiteit van een democratie als democratie. ${ }^{26} \mathrm{Het}$ is in dit voorbeeld eerder de legitimiteit van de rechtsstaat die het moet ontgelden, aangezien het recht op een eerlijk proces een typisch rechtsstatelijk principe is. Voor hate speech geldt volgens Heinze hetzelfde: hoe verwerpelijk deze praktijk ook mag zijn, het doet niet af aan de legitimiteit van de democratie, aangezien het verbod op hate speech niet aan de legitimiteit van de democratie bijdraagt. Het draagt hooguit bij aan de legitimiteit van de rechtsstaat, die de rechten van individuen moet beschermen - al valt daar in het geval van hate speech ook aan te twijfelen omdat een beledigende, haatdragende of discriminerende opmerking op zich nog geen materiële schending of intrekking van rechten oplevert. ${ }^{27}$

Kortom, zolang burgers en hun politieke vertegenwoordigers in het publieke debat standpunten innemen over een onderwerp dat geoorloofd is, bestaat er geen democratische grond om die standpunten te censureren of te bestraffen. Er kunnen wellicht rechtsstatelijke gronden zijn om zulke uitingen te verbieden, maar deze staan per definitie op gespannen voet met het democratische gehalte van wetgeving en bestuur. Door democratische en liberale principes op deze manier van elkaar te onderscheiden, iets wat door liberale denkers als Dworkin en Waldron niet consequent wordt gedaan, wordt eerst inzichtelijk dat de vrijheid van meningsuiting in het publieke debat niet een van de vele constitutionele beginselen is, maar veeleer, zoals Heinze het treffend formuleert, 'de constitutie van de democratische constitutie'. Met dit uitgangspunt in het achterhoofd is goed in te zien waarom de vrijheid van meningsuiting niet alleen als algemeen grondrecht (gericht op bescherming van het individu) maar tevens in de vorm van

Zie meer algemeen Heinze, Hate speech and democratic citizenship (2016), par. 4.6.

Heinze, Hate speech and democratic citizenship (2016), 50 e.v.

Heinze spreekt in dit verband ook van de denial fallacy. Dit houdt in: de vereenzelviging van een politiek voornemen ('wij willen discrimineren/u zou moeten discrimineren') met de verwezenlijking daarvan ('er wordt gediscrimineerd'). Om bij het voorbeeld te blijven: Waldron suggereert dat het uitspreken van het voornemen om te discrimineren of het aanzetten daartoe reeds een schending (denial) van het recht op gelijke behandeling kan opleveren, nu dit de basale waardigheid van mensen in twijfel trekt. Zie Waldron, The Harm in Hate Speech (2012), 83. 'Hate speech or group defamation involves the expressed denial of these fundamentals with respect to some group in society'. Volgens Heinze echter staat het streven om mensen hun rechten te ontzeggen nog niet gelijk aan de politieke verwerkelijking daarvan. 
de parlementaire immuniteit (gericht op de bescherming van het democratische debat) in de Grondwet is vastgelegd. Waarom deze dubbele verankering niet alleen relevant is voor het publieke debat en de democratie maar tevens voor het principe van machtenscheiding, zal in de volgende paragraaf worden besproken.

\subsection{Parlementaire immuniteit, machtenscheiding en legaliteit}

Uit de bovenstaande bespreking van de relatie tussen het publieke debat en de democratie volgt dat de vrijheid van meningsuiting, die een vrij en open publiek debat mogelijk maakt, een zeker primaat binnen de constitutionele orde toekomt. ${ }^{28}$ Toch is dit op het eerste gezicht niet af te lezen aan de Nederlandse Grondwet, nu art. $7 \mathrm{Gw}$, waarin het algemene censuurverbod is neergelegd, geen bijzondere plek inneemt ten opzichte van andere grondrechten. Hetzelfde geldt voor artikel10 Europees Verdrag voor de Rechten van de Mens (EVRM), dat in beginsel op gelijke voet staat met andere fundamentele mensenrechten. Wie de Grondwet daarentegen wat uitgebreider bestudeert, zal opmerken dat zij, net als vrijwel elke democratische constitutie, een norm bevat die wel degelijk aansluit op het primaat van de vrijheid van meningsuiting zoals bepleit door Heinze, namelijk de parlementaire immuniteit (art. $71 \mathrm{Gw}$ ). Deze regeling houdt in dat de leden van de Staten-Generaal en andere personen die deelnemen aan de beraadslagingen niet gerechtelijk vervolgbaar zijn voor alles wat zij schriftelijk aan de vergadering meedelen of tijdens de vergadering uitspreken. De immuniteit kan niet worden opgeheven, wat betekent dat de vrijheid van meningsuiting in het parlement vrijwel onbegrensd is. ${ }^{29}$

Met artikel $71 \mathrm{Gw}$ heeft de grondwetgever kennelijk willen onderstrepen dat de vrije uitwisseling van politieke standpunten van wezenlijk belang is voor het functioneren van een democratie. In die zin sluit de regel goed aan op de overwegingen van Heinze over het fundamentele karakter van de publieke discussie voor democratisch burgerschap. Daar kan natuurlijk tegenin worden gebracht dat de parlementaire immuniteit alleen bescherming biedt aan de parlementaire discussie en daarom niets te betekenen heeft voor gewone burgers. ${ }^{30}$ Maar dat is te kort door de bocht. Volksvertegenwoordigers - de naam zegt het al - zijn immers niet slechts de leden van het instituut parlement maar tevens de afgevaardigden van het volk. Zij zijn dus niet volledig onafhankelijke actoren binnen een volledig zelfstandig politiek systeem maar vormen juist een intermediair tussen de burgers en de politiek. ${ }^{31}$ De bijzondere bescherming van

28 Dit begrip leen ik van J.A. Peters, Het primaat van de vrijheid van meningsuiting. Vergelijkende aspecten Nederland-Amerika (Nijmegen: Ars Aequi Libri, 1981).

29 Hierbij dient de kanttekening te worden geplaatst dat de leden van de Staten-Generaal en andere deelnemers aan de beraadslagingen wel degelijk in hun vrijheid van meningsuiting kunnen worden beperkt door de voorzitter van de vergadering. Dit ingrijpen heeft echter geen strafrechtelijke maar een parlementair-reglementaire grondslag en kan slechts nadat een concrete uitspraak is gedaan enig effect sorteren. Daarin verschilt een parlementaire maatregel van de voorzitter danig van het strafrecht in de zin dat daarvan in veel mindere mate een preventieve of afschrikkende werking uitgaat.

30 Zie in dit verband E.C.M. Jurgens, 'Een gedurfde stelling', TvCR afl. 3 (2010), 322-326.

31 Ter illustratie, zie EHRM 23 april 1992, Castells v. Spanje, NJ 1994, 102, m. nt. E.J. Dommering. 
artikel $71 \mathrm{Gw}$ moet om die reden niet uitsluitend worden opgevat als een juridisch-staatkundig instrument dat de onafhankelijkheid van het parlement en individuele parlementariërs moet beschermen, maar tevens als een breder, democratisch principe dat de band tussen kiezers en gekozenen schraagt en in stand houdt. De immuniteit is zo bezien tevens een uitdrukking van het beginsel van volkssoevereiniteit.

Deze dubbele betekenis is ook tot uitdrukking gebracht door Thorbecke, die bij de grondwetsherziening in 1848 nadrukkelijk voor de invoering van de huidige immuniteitsregeling heeft gepleit. Kamerleden moesten naar zijn opvatting niet bevreesd zijn voor vervolging omdat zij zich onverwrikt moesten kunnen uitspreken over wat nuttig en noodzakelijk is voor het landsbelang. ${ }^{32}$ Oud duidde het beginsel later op vergelijkbare wijze: 'De parlementaire immuniteit zorgt ervoor [...] dat het Kamerlid niet uit vrees voor den rechter ervan wordt weerhouden datgene te zeggen wat hij in het openbaar belang wenst uit te spreken. ${ }^{33}$ Naast de onafhankelijkheid van het parlement ten opzichte van de uitvoerende en rechtsprekende macht (de institutionele dimensie) moet dus ook de uiting en de uitwisseling van standpunten in het openbaar belang (de democratische dimensie) als voorwerp van de immuniteit worden gezien. Daarmee staat de regeling uiteraard nog niet gelijk aan een bredere, burgerlijke vrijheid in het publieke debat zoals Heinze die voor ogen heeft, maar het ligt wel degelijk in het verlengde daarvan. De parlementaire immuniteit fungeert, bezien vanuit de functie van de volksvertegenwoordiging als intermediair tussen het volk en de politiek, als een juridische ruggengraat van het vrije politieke debat. ${ }^{34}$

Tegelijkertijd kan worden betwijfeld of de huidige immuniteitsregeling deze ruggengraatfunctie nog adequaat kan vervullen. Haar reikwijdte is immers beperkt tot de parlementaire vergadering, en een groot deel van het politiekmaatschappelijke debat speelt zich tegenwoordig buiten het parlement af. Sommigen pleiten daarom voor uitbreiding van het bereik van artikel $71 \mathrm{Gw}$, zodat Kamerleden zich ook buiten de parlementaire vergadering kunnen uitspreken zonder vrees voor vervolging. ${ }^{35}$ Volgens Nehmelman, die herhaaldelijk voor een dergelijke uitbreiding heeft gepleit, kan dit op twee punten een heilzaam effect hebben. Ten eerste stelt de uitgebreide immuniteit volksvertegenwoordigers beter in staat om hun centrale opdracht, namelijk het

32 D.J. Elzinga, 'Parlementaire onschendbaarheid voor volksvertegenwoordigers', in De staat van het recht. Opstellen over staatsrecht en politiek, D.J. Elzinga (Zwolle: Tjeenk Willink, 1990), 120.

33 Citaat in: Handelingen Nederlandse Juristen Vereniging 2013(2), jaargang 14318.

34 Voor het EHRM is dit, interessant genoeg, reden om de parlementaire discussie ook onder de bescherming van artikel 10 EVRM te laten vallen, omdat het parlement volgens het hof - in de woorden van Nieuwenhuis - als 'een brandpunt van de maatschappelijke discussie' moet worden gezien. Zie Nieuwenhuis, Tussen grondrechtelijke vrijheid en parlementaire onschendbaarheid: de vrijheid van meningsuiting van de parlementariër' (2010), 13.

35 J.A. Peters, 'Immuniteit ook buiten het parlementair debat', (2010), 327-330; Nehmelman, 'Spreken is zilver, maar wie bepaalt wanneer zwijgen goud is' (2011), 355-360; Nehmelman, 'Uitbreiding van de parlementaire immuniteit' (2013), 243-262. 
articuleren en omzetten van de standpunten van kiezers, te volbrengen. ${ }^{36}$ Voorts acht Nehmelman uitbreiding wenselijk omdat dit de scheiding der machten, in het bijzonder die tussen de wetgever en de rechter, ten goede komt. Hoe groter het bereik van de immuniteit, zo is ongetwijfeld zijn gedachte, hoe minder snel volksvertegenwoordigers met de (straf)rechter in aanraking kunnen komen en hoe kleiner de kans van een onwenselijke inmenging van de rechtspraak in de politiek. $^{37}$

Daarbij is de zekerheid van onvervolgbaarheid die de regeling in het vooruitzicht stelt ongetwijfeld het belangrijkst. Het is gemakkelijk in te zien waarom: wie er zeker van is dat hij niet zal worden vervolgd, zal bij het innemen van standpunten geen inhoudelijke zelfcensuur toepassen. Om de publieke discussie dus zo democratisch mogelijk te laten verlopen, is de zekerheid dat er niet onverwacht inhoudelijke beperkingen aan die discussie worden gesteld een belangrijke voorwaarde. Een centraal doel van de immuniteit is dan ook het voorkomen van wat in de literatuur wel wordt aangeduid als een chilling effect: het toepassen van zelfcensuur met betrekking tot uitlatingen over bepaalde, controversiële onderwerpen als gevolg van onzekerheid over de toelaatbaarheid daarvan. ${ }^{38}$ Omdat uitbreiding van de parlementaire immuniteit de strafrechter op grotere afstand van het politieke debat plaatst en de parlementariër zodoende meer zekerheid biedt, kan dit de toepassing van zelfcensuur onder politici voorkomen.

Zolang van een bredere immuniteit echter geen sprake is, leunt de rechtszekerheid van politici buiten het parlement echter vooral op het lex certavereiste: de van het legaliteitsbeginsel afgeleide norm die een duidelijke omschrijving en navolgbare toepassing van strafwet vereist. Om dit punt te illustreren kan op de zogeheten void-for-vagueness-doctrine van het Amerikaanse hooggerechtshof worden gewezen. Deze doctrine houdt in dat wanneer een strafbepaling, die zo vaag is dat de gemiddelde rechtsdeelnemer moet raden wat wel en niet is toegestaan, de betreffende bepaling als ongrondwettelijk moet worden bestempeld. ${ }^{39}$ Op basis van deze stelregel kan worden voorkomen dat 'people at the fringes of amenability to regulation will rather obey than run the

36 Nehmelman, 'Spreken is zilver, maar wie bepaalt wanneer zwijgen goud is' (2011), 359; Nehmelman, 'Uitbreiding van de parlementaire immuniteit' (2013), 259.

37 Nehmelman plaatst daarbij nadrukkelijk de kanttekening dat de uitgebreide immuniteit alleen van toepassing moet zijn op politieke uitlatingen; alles wat politicus als privé-persoon zegt valt hier niet onder. In de Franse en Belgische grondwetten, waar de uitgebreide immuniteit een gevestigde constitutionele norm is, vinden we een dergelijk onderscheid ook terug. Zo is de immuniteit in België, als geformuleerd in artikel 58 van de Grondwet, slechts toepasselijk op 'een mening of een stem, in de uitoefening van zijn functie uitgebracht'. Zie voor een nadere toelichting op dit punt Nehmelman, 'Uitbreiding van de parlementaire immuniteit' (2013), 248-250.

38 A.L.J. Janssens \& A.J. Nieuwenhuis, Uitingsdelicten (Deventer: Wolters Kluwer, 2011), 249. Zie ook R. Blommestijn \& M. Klos, 'Een giftige paddenstoel voor de vrijheid van meningsuiting: Bol.com en het verbieden van 'foute' boeken', NJB afl. 19 (2020), 1392 e.v.

39 M. Boot, Nullem crimen sine lege and the Subject Matter Jurisdiction of the International Criminal Court (PhD diss. Antwerpen: Intersentia, 2005), 120. 
risk of erroneous constitutional judgement'. ${ }^{40}$ Dezelfde verwachting ligt ten grondslag aan het lex certa-vereiste: als een strafbepaling onvoldoende duidelijk is geformuleerd, ligt het voor de hand dat de rechtsdeelnemer zich uit vrees voor een onverwachte sanctie terughoudender gaat opstellen. ${ }^{41}$ Het aanpassen of schrappen van die bepaling is dan, vanuit het ideaal van rechtsbescherming, een logische stap.

Voor zover politici en andere deelnemers aan het politiek-maatschappelijke debat met strafrechtelijke normen worden geconfronteerd, zullen die normen - de doelstelling van de parlementaire immuniteit indachtig - zo duidelijk mogelijk moeten zijn geformuleerd om rechtsonzekerheid, en daarmee zelfcensuur, tegen te gaan. Zo bezien spelen de parlementaire immuniteit en het legaliteitsbeginsel een vergelijkbare rol bij het bevorderen van de legitimiteit van de democratie, nu beide principes, mits zij in voldoende mate worden gerespecteerd, bijdragen aan de verduidelijking van de juridische marges van het publieke debat en zodoende een chilling effect kunnen voorkomen. Een belangrijk verschil tussen beide beginselen is echter dat de naleving van de parlementaire immuniteit voor zijn werking niet afhankelijk is van de wetgever of de rechter, terwijl de naleving van het legaliteitsbeginsel (in het bijzonder: het lex certa-vereiste) juist volledig van de welwillendheid van de wetgever en - in tweede instantie - de rechter afhankelijk is. Het is bij de beoordeling van de formulering en toepassing van de artikelen 137 c en 137d Sr, die in volgende paragraaf aan de orde komt, dan ook van groot belang om de rol en verantwoordelijkheid van beide instituties te betrekken.

\section{Begrenzing van de vrijheid van meningsuiting: de rol van de rechter}

Hierboven is uiteengezet dat het vrije publieke debat in zekere zin ten grondslag ligt aan de democratische constitutie en om die reden geen voorwerp mag worden van op standpunten gebaseerde sancties. Daarvoor is de publieke discussie simpelweg te wezenlijk als het gaat om de legitimiteit van de democratie. Verder is duidelijk geworden dat de publieke discussie in laatste instantie wordt beschermd door de parlementaire immuniteit, omdat deze regeling de uitspraken van volksvertegenwoordigers (inclusief de standpunten die zij namens burgers innemen) categorisch afschermt van strafrechtelijke interventie. Aangezien de reikwijdte van deze regeling echter beperkt is tot de parlementaire vergadering, zal de mate waarin het politiek-maatschappelijke debat buiten het parlement bescherming geniet aan de hand van andere constitutionele normen moeten worden getoetst. Zoals hierboven is uiteengezet, speelt het legaliteitsbeginsel daarbij een essentiële rol omdat aan de hand van dit beginsel kan worden beoordeeld of strafbepalingen, en zo ook de uitingsdelicten 137c en 137d Sr,

40 Citaat uit A.G. Amsterdam, 'The Void-for-vagueness Doctrine in the Supreme Court', University of Pensilvania Law Review 109 (1960), overgenomen uit Boot, Nullem crimen sine lege and the Subject Matter Jurisdiction of the International Criminal Court (2005), 120.

41 J.S. Nan, Het lex certa-beginsel (Den Haag: Sdu Uitgevers, 2011), 79-80. Zie ook Boot, Nullem crimen sine lege and the Subject Matter Jurisdiction of the International Criminal Court (2005), 96. 
duidelijk kenbare normen bevatten. In deze paragraaf zal in kort bestek een poging worden ondernomen tot een dergelijke beoordeling; een stap die van belang is voor de beantwoording van de hoofdvraag, omdat wanneer de inhoud en toepassing van deze bepalingen niet aan het bepaaldheidsvereiste voldoen, dit een erosie van zowel het vrije publieke debat als de machtenscheiding kan betekenen.

\subsection{Begrenzing van de vrijheid van meningsuiting: algemeen}

De vrijheid van meningsuiting wordt in Nederland beschermd door artikel 7 Grondwet. Hierin is een algemeen censuurverbod neergelegd. Nog belangrijker dan het Nederlandse censuurverbod is het in artikel 10 EVRM vastgelegde recht op vrijheid van expressie, dat gezien de directe doorwerking van eenieder verbindende bepalingen uit verdragen het primaat geniet. ${ }^{42}$ De rechter laat zich daarom in toenemende mate leiden door de inhoud van dit artikel en de daaruit voortgekomen jurisprudentie van het Europees Hof (EHRM). Dat is op zich een positief gegeven, want in tegenstelling tot het grondwetsartikel bevat de verdragsbepaling strengere eisen voor het toetsen van strafrechtelijke beperkingen. ${ }^{43}$ We lopen die eisen eerst in grote lijnen na.

Allereerst vereist artikel 10 EVRM dat een beperking van de vrijheid van expressie altijd moet zijn voorgeschreven door de wet (proscribed by law). Dit betekent onder meer dat een beperking voorzienbaar (foreseeable) moet zijn. Hoewel dit doet vermoeden dat hier het lex certa-vereiste een rol van betekenis speelt, struikelen beperkingen zelden op dit punt. ${ }^{44} \mathrm{Als}$ een beperking in een formele wet is vastgelegd, is dat doorgaans voldoende. De tweede eis ziet op het doel van de beperking. Lid 2 van artikel 10 bevat een opsomming van doelen, waarin onder meer de nationale veiligheid, het voorkomen van wanordelijkheden en de bescherming van de rechten van anderen worden genoemd. Onder de laatstsgenoemde categorie vallen delicten als groepsbelediging (art. 137c Sr) en het aanzetten tot haat of discriminatie (art. 137d Sr). Net als de eerste toets levert deze tweede stap dikwijls geen problemen op; de rechter moet de beperking simpelweg onder een van de vooraf gestelde doelen zien te brengen. Dat is een heel ander verhaal bij het derde toetsingscriterium: de vraag of een beperking 'noodzakelijk is in een democratische samenleving'. Daarbij moet de rechter nagaan of een beperking wordt gerechtvaardigd door een 'pressing social need' en of deze proportioneel is ten opzichte van het nagestreefde doel. ${ }^{45}$ Het feit dat het dit betrekkelijk open normen zijn, geeft al aan dat de derde toets niet altijd even gemakkelijk is, hetgeen in paragraaf 4 duidelijk naar voren zal komen.

Nog voordat de rechter aan de moeilijke opgave van de proportionaliteitstoets toekomt, zal hij zich moeten buigen over de concrete strafbepalingen waar een beperking op gebaseerd is. Daarbij zal hij de bestanddelen van de delicts-

42 Nieuwenhuis, Over de grens van de vrijheid van meningsuiting (2015), 209.

43 Nieuwenhuis, Over de grens van de vrijheid van meningsuiting (2015), 316 e.v.

44 Nieuwenhuis, Over de grens van de vrijheid van meningsuiting (2015), 316.

45 Nieuwenhuis, Over de grens van de vrijheid van meningsuiting (2015), 317. 
omschrijvingen en de daarin in vervatte begrippen moeten interpreteren en toepassen, wat in het geval van de artikelen 137c en 137d Sr evenmin als bij de proportionaliteitstoets een gemakkelijke opgave is. Waaruit dat blijkt, zal hieronder aan de hand van enkele voorbeelden worden besproken.

\subsection{De uitingsdelicten $137 c$ en $137 d W v S$}

Allereerst iets over de inhoud en de voorgeschiedenis van deze bepalingen. Artikel. 137c stelt strafbaar het zich in het openbaar opzettelijk beledigend uitlaten over een groep mensen wegens hun ras, godsdienst of levensovertuiging, hetero- of homoseksuele gerichtheid of lichamelijke, psychische of verstandelijke handicap. In artikel 137d wordt hij die in het openbaar aanzet tot discriminatie, haat of gewelddadig optreden tegen een groep mensen wegens hun ras, godsdienst of levensovertuiging, geslacht, hun hetero- of homoseksuele gerichtheid of lichamelijke, psychische of verstandelijke handicap met straf bedreigd. Voor beide delicten kan de rechter maximaal een jaar vrijheidsbeneming of een geldboete van de derde categorie opleggen.

De ontstaansgeschiedenis van artikel 137c gaat terug tot de jaren dertig van de vorige eeuw, toen de wetgever het noodzakelijk achtte om 'ordeverstoring en relletjes' als gevolg van stelselmatige beledigingen aan het adres van bepaalde bevolkingsgroepen - in de eerste plaats de joodse - strafrechtelijk te sanctioneren. ${ }^{46}$ Het oude delict groepsbelediging paste daarmee onder de titel 'Misdrijven tegen de openbare orde'. In 1971 is artikel 137c grondig gewijzigd en werd het voor het eerst geflankeerd door artikel 137d. Aanleiding voor deze aanpassing was de ratificatie van het Internationaal verdrag inzake de uitbanning van alle vormen van rassendiscriminatie (IVURD) in 1966, dat Nederland verplichtte tot het nemen van wettelijke stappen ter bestrijding van rassendiscriminatie. Deze maatregelen werden door de meeste westerse verdragsstaten beschouwd als een reactie op de mensonterende toestanden die zich in de Tweede Wereldoorlog hadden voorgedaan onder het nationaalsocialisme. ${ }^{47}$

Opmerkelijk is dat de Nederlandse wetgever destijds de behoefte noch de noodzaak zag om in Nederland extra wettelijke maatregelen te nemen ter bestrijding van rassendiscriminatie, aangezien dit reeds op grond van het algemene gelijkheidsbeginsel in de Grondwet (destijds art. 4) als onwettig werd gezien. ${ }^{48}$ Dat er voor is gekozen om naast de invoering van een nieuwe, tegen (rassen)discriminatie gerichte bepaling (art. 137d), strafbare groepsbelediging (art. 137c) in het Wetboek van Strafrecht te handhaven - ondanks dat dit op

Handelingen II 1933/1934, 237, nr. 3, 3. Voor een beknopt overzicht van de ontstaansgeschiedenis van art. 137c en 137d Sr, zie T. Herrenberg, 'Een overzicht van groepsbelediging en aanzetten tot haat of discriminatie', in De grenzen van het publieke debat, red. T. Herrenberg (Den Haag: Boom Juridisch, 2019), 17-45.

47 Janssens \& Nieuwenhuis, Uitingsdelicten (2011), 196.

48 Memorie van Toelichting, 1967-1968, 9724, nr. 3, 3. 
grond van het IVURD niet verplicht was - is dan ook opvallend. Te meer omdat de regering ten aanzien van dit delict het volgende opmerkte:

'Bij het ontwerpen van strafbepalingen ter zake van belediging van groepen moet grote voorzichtigheid worden betracht [...]. Het strafrecht nu kan slechts in geringe mate bijdragen tot het oplossen van maatschappelijke spanningen. Toepassen ervan kan zelfs leiden tot verscherping van het conflict. Voorts is de vrijheid van meningsuiting in het geding. Elke onnodige beperking daarvan is te verwerpen. ${ }^{49}$

Wat betreft de inhoud van het begrip 'ras' in de artikelen 137c en 137d Sr maakte de wetgever eveneens een opvallende keuze. Ondanks dat dit begrip bewust in een limitatieve opsomming is geplaatst omwille van de duidelijkheid, kende de wetgever aan het begrip 'ras' een betrekkelijk ruime definitie toe. ${ }^{50}$ Deze definitie is vastgelegd in artikel 1 IVURD, waarin naast de term 'ras' ook 'nationale en etnische afstamming', 'huidskleur' en 'afkomst' worden genoemd. Dat deze gelaagdheid van het begrip 'ras' twijfel zou kunnen oproepen over de interpretatie van dit begrip kon de wetgever blijkens de Memorie van Antwoord niet inzien. In een poging sceptische Kamerleden evenwel gerust te stellen, verklaarde de regering dat een kwalificatie als 'de gastarbeiders' niet onder het bereik van de bepalingen zou vallen. ${ }^{51}$

Dat deze toezegging niet of nauwelijks betekenis mocht hebben, werd reeds duidelijk in 1986 toen de Hoge Raad een veroordeling tegen het Tweede Kamerlid Hans Janmaat voor groepsbelediging in stand hield. ${ }^{52}$ In deze zaak ging het om een televisie-uitzending waarin Janmaat kritiek had geuit op de naturalisatie van 'vreemdelingen die het Nederlanderschap willen verkrijgen'. Ter illustratie van zijn standpunt had Janmaat onder meer verwezen naar een 'Turk met een misdadig verleden' die volgens hem vanwege zijn gedrag geen recht zou mogen hebben op naturalisatie. Deze uitlatingen werden door het hof opgevat als belediging van een groep mensen wegens hun 'ras'. ${ }^{53}$ Een beroep op het legaliteitsbeginsel bij de Hoge Raad mocht Janmaat niet baten, omdat de wetgever aan het begrip 'ras' in artikel 137c nu eenmaal een ruime betekenis had toegekend. Dat uit de wetsgeschiedenis bleek dat de wetgever de term 'de gastarbeiders' buiten het bereik van artikel 137c wilde houden, deed aan die conclusie niets af. ${ }^{54}$

Eind jaren negentig kwam Janmaat wederom met de rechter in aanraking, ditmaal omdat hij tijdens een openbare demonstratie had gezegd: 'Wij schaffen zodra wij de mogelijkheid en de macht hebben de multi-culturele samenleving af'. 
Dit leverde hem een veroordeling op voor het aanzetten tot discriminatie van 'buitenlanders' wegens hun 'ras'. Wederom hield de Hoge Raad de veroordeling van het hof in stand, waarbij doorslaggevend was dat Janmaats uitspraken moesten worden bezien in samenhang met de uitspraken van andere aanwezigen zoals 'Nederland voor de Nederlanders', 'Eigen volk eerst' en 'Vol is vol'. Die combinatie leverde volgens het Arnhemse hof de eenduidige conclusie op dat Janmaat had opgeroepen tot 'de verwijdering van (leden van) etnische minderheden uit de Nederlandse samenleving. ${ }^{55}$ Hoewel de verdachte noch het begrip 'buitenlanders' had gebezigd noch concreet over (beleid omtrent) een bepaalde etnische minderheid had gesproken, mocht het hof deze karakterisering vanwege de hierboven genoemde context toch aan hem toeschrijven.

In weer een ander opvallend voorbeeld oordeelde het Gerechtshof Amsterdam dat de uitlatingen van een gemeenteraadslid over 'vreemdelingen' en 'Islamieten' konden worden gelezen als te zijn gericht tegen mensen met een bepaalde etnische afstamming. ${ }^{56}$ Daarmee vielen de uitlatingen van de verdachte, ondanks dat hij niet naar een concrete etniciteit of afkomst had verwezen, onder de categorie 'ras' in de zin van artikel 137d. De zaak resulteerde in een veroordeling voor het aanzetten tot haat, wederom op basis van een zeer ruime interpretatie van het begrip 'ras'. In cassatie stond de vraag centraal of de verdachte als lid van de gemeenteraad een beroep kon doen op de hierboven besproken parlementaire immuniteit (in dit geval art. 22 van de Gemeentewet). De Hoge Raad oordeelde dat dit beroep faalde: de verdachte had de strafbare uitlatingen weliswaar gedaan tijdens een zitting van de gemeenteraad - alwaar hij immuniteit genoot - maar omdat hij zijn redevoering aan een journalist had overhandigd met het oogmerk op publicatie daarvan, viel de uitlating alsnog onder de 'gewone' vrijheid van meningsuiting en dus onder het bereik van artikel 137d. ${ }^{57}$ Deze zaak markeert dan ook treffend het scherpe juridische onderscheid tussen parlementair en publiek debat dat de beperkte Nederlandse immuniteitsregeling in het leven roept.

De veroordeling van PVV-leider Geert Wilders door de rechtbank Den Haag in 2016 valt eveneens op, in minstens twee opzichten. Allereerst werd er in deze zaak, net als in de bovengenoemde zaken, getwist over de reikwijdte van het begrip 'ras'. Volgens de verdediging was de uitlating van Wilders over 'minder Marokkanen' die hij deed tijdens een partijbijeenkomst in Den Haag, uitsluitend gericht op 'criminele Marokkanen' en zag zij niet op hun 'afkomst' of 'etnische afstamming' maar op hun 'nationaliteit'; een categorie die naar de letter van het IVURD inderdaad buiten het bereik van de strafwet valt. Nagenoeg zonder onderbouwing concludeerde de rechtbank daarentegen dat de uitlating van Wilders wel degelijk betrekking had op de 'gemeenschappelijke afkomst' van Marokkanen en daarom binnen het bereik viel van de artikelen 137c en 137d Sr. ${ }^{58}$ Daar komt bij dat rechtbank er vrij gemakkelijk vanuit is gegaan dat Wilders de

HR 18 mei 1999, NJ 1999, 634.

HR 2 april 2002, ELCI:NL:HR:2002:AD8693, m.nt. P.A.M. Mevis.

HR 2 april 2002, ELCI:NL:HR:2002:AD8693, m.nt. P.A.M. Mevis.

Rb. Den Haag, 9 december 2016, ECLI:NL:RBDHA:2016:15014 (Wilders II), par. 5.4.2. 
hele Marokkaanse bevolkingsgroep 'als minderwaardig ten opzichte van andere Nederlanders' heeft weggezet en als zodanig in haar eigenwaarde heeft aangetast. ${ }^{59}$ Ook voor deze conclusie draagt de rechtbank nauwelijks een onderbouwing aan, wat de vraag oproept in hoeverre de rechter over de kennelijke bedoeling van een verdachte kan en mag speculeren. Te meer omdat Wilders zelf in alle toonaarden ontkent dat hij Marokkanen als inferieur heeft afgeschilderd en dat hij slechts een politiek voorstel tot immigratiebeperking wilde doen.

\subsection{De strafrechter: ook een geschikte scheidsrechter?}

Als we de bovengenoemde voorbeelden kritisch tegen het licht houden, lijken zich in ieder geval twee problemen te openbaren. Ten eerste blijkt dat het begrip 'ras' in de artikelen 137c en 137d Sr geen eenduidige, op voorhand kenbare betekenis heeft, omdat de wetgever aan dit begrip een buitenwettelijke definitie heeft toegekend. Om die reden kan het voor de gemiddelde rechtsdeelnemer op voorhand onduidelijk zijn op welke groepen deze delicten precies betrekking hebben. Wie een opmerking maakt over 'islamieten', 'vreemdelingen', 'buitenlanders' of 'Marokkanen' kan moeilijk inschatten of dit een veroordeling voor groepsbelediging of het aanzetten tot haat of discriminatie kan opleveren. Wat is, om bij het voorbeeld van de zaak-Wilders te blijven, immers het wezenlijke verschil tussen de categorie 'nationale afstamming', die onder het bereik van 137c en 137d Sr valt, en 'nationaliteit', die nadrukkelijk van strafbaarheid is uitgesloten? Bovendien blijkt dat de rechter het begrip 'ras' zeer extensief kan interpreteren, zodat een begrip als 'buitenlanders', dat niet eens aan een concrete etniciteit of nationale afkomst is gekoppeld, toch als 'ras' in de zin van de strafwet kan gelden.

Het tweede probleem is dat de rechter in sommige gevallen ronduit speculeert over welke kwalificatie een verdachte precies voor ogen had of wat hij met een uitlating heeft bedoeld. Weliswaar zijn dergelijke speculaties in sommige gevallen noodzakelijk om het beledigende of discriminerende aspect van een opmerking te kunnen bewijzen, zoals de veronderstelde inferioriteit van Marokkanen bij Wilders of Janmaats veronderstelde streven tot de uitzetting van etnische minderheden, maar het resultaat is dat beide veroordelingen daardoor een nogal gekunstelde en ietwat willekeurige indruk maken. Dit probleem doet zich voornamelijk voor bij artikel 137d Sr, omdat dit delict niet vereist dat de handeling waartoe wordt aangezet, namelijk discriminatie van een bepaalde groep, daadwerkelijk heeft plaatsgevonden. ${ }^{60}$ Het rechtsdoel van deze bepaling is immers niet primair het beschermen van groepen tegen daadwerkelijke ongelijke behandeling, als wel het beschermen tegen de mogelijke of dreigende inbreuk op dit recht. ${ }^{61}$ Er zit, met andere woorden, reeds op voorhand een speculatief element in

59 Rb. Den Haag, 9 december 2016, ECLI:NL:RBDHA:2016:15014 (Wilders II), par. 5.4.3.

60 Zie in dit verband voetnoot 27.

61 Voor een interessante rechtstheoretische bespiegeling over dit punt, zie Heinze, Hate speech and democratic citizenship (2016), 169-175. 
deze bepaling ingebakken, waardoor het ook niet zo verwonderlijk is dat de rechter soms over de intenties van een verdachte moet fantaseren.

Dit alles beidt weinig hoop voor de rechtszekerheid. Afgaand op de hierboven gegeven voorbeelden blijkt dat zowel de formulering als de toepassing van de artikelen $137 \mathrm{c}$ en 137d $\mathrm{Sr}$ op gespannen voet kan staan met het legaliteitsbeginsel en meer in het bijzonder het lex certa-vereiste. Zoals reeds is besproken in paragraaf 2.2, vereist dit beginsel dat elke strafbepaling een zekere voorzienbaarheid aan de dag legt met het oog op de rechtszekerheid; een eis die juist bij de uitingsdelicten een wezenlijke rol speelt vanwege het gevaar van onwenselijke terughoudendheid bij het uiten van politieke standpunten (het eerder genoemde chilling effect). Het voorkomen van dit effect is in de eerste plaats een verantwoordelijkheid van de wetgever, die kennelijk noch bij de totstandkoming noch in de loop van het vijftigjarige bestaan van de artikelen 137c en 137d Sr oog heeft gehad voor dit risico, ondanks uiteenlopende waarschuwingen. ${ }^{62}$ Tegelijkertijd ligt de verantwoordelijkheid voor het bevorderen van de rechtszekerheid niet uitsluitend bij de wetgever. Ook de rechter speelt daarbij een bepalende rol. Door reeds vage of onduidelijke delictsbestanddelen nog verder op te rekken of door te speculeren over de bedoelingen achter de uitspraken van verdachten, kan de rechter niet alleen de rechtszekerheid verder onder druk zetten maar tevens het verwijt over zich afroepen dat hij zich actief met de marges van het politieke debat bemoeit. ${ }^{63}$ Dat is een verwijt dat het aanzien van de rechterlijke macht, die de fragiele reputatie van een onafhankelijk en onpartijdig instituut hoog te houden heeft, ernstig kan beschadigen.

Teneinde dit te voorkomen zou de rechter zich terughoudender kunnen opstellen, om te beginnen door de hier besproken uitingsdelicten zoveel mogelijk restrictief te interpreteren. ${ }^{64}$ Omdat hiervoor - juist met het oog op de onafhankelijkheid van de rechter - echter geen garanties te geven zijn, is de hoop op restrictieve interpretatie op de lange termijn onvoldoende om het probleem van rechtsonzekerheid en een dreigend chilling effect te ondervangen. Daarvoor is, zoals Heinze suggereert, een meer categorische bescherming van het publieke debat nodig. Aangezien de wetgever op dit punt echter geen actie blijkt te ondernemen, rijst toch de vraag of de rechter zelf een zinvolle oplossing kan bieden. In de volgende paragraaf zal deze vraag daarom uitgebreid aan de orde worden gesteld.

62 Goede voorbeelden zijn M.S. Groenhuijsen, Straf en wet (Arnhem: Gouda Quint, 1987), 22 en Th. Rosier, 'Discriminerende belediging', Recht \& Kritiek afl. 4 (1996), 305-333; P.B. Cliteur, Barbot, Fallaci, Houellebecq en Wilders: gerechtelijke vervolging van religiekritiek en vreemdelingenvrees (Groningen: De Blauwe Tijger, 2016).

63 Nieuwenhuis komt tot een vergelijkbare conclusie: 'Wanneer de grenzen vaag zijn, zal ook eerder het idee kunnen ontstaan dat een proces tegen een politicus - van de oppositie - een politiek proces is'. Nieuwenhuis, 'Tussen grondrechtelijke vrijheid en parlementaire onschendbaarheid: de vrijheid van meningsuiting van de parlementariër' (2010), 23.

64 A. Ellian \& P.B. Cliteur, De staat versus Wilders (Den Haag: Boom Juridisch, 2019), 141-142. Zie ook M.S. Groenhuijsen, Straf en wet (1987), 22-23. 


\section{Contextuele toetsing: een heilzame oplossing of olie op het vuur?}

Hierboven is stilgestaan bij enkele voorbeelden van de manier waarop de rechter de uitingsdelicten in 137c en 137d Sr in de loop der tijd heeft toegepast. Daaruit is naar voren gekomen dat deze bepalingen op het punt van de rechtszekerheid beduidend tekortschieten, met als mogelijk gevolg dat de vrije uitwisseling van standpunten en ideeën die in een parlementaire democratie noodzakelijk is een zogeheten chilling effect ontmoet. In deze paragraaf zal worden onderzocht of de rechtspraak van de Hoge Raad deze zorg kan wegnemen. Onder invloed van het EHRM heeft 's lands hoogste rechter namelijk meer oog gekregen voor de bescherming van uitlatingen die 'dienstig zijn aan het maatschappelijk debat' en dit omgezet in een algemeen toetsingskader voor de artikelen 137c en 137d Sr. Hieronder zal dit toetsingskader nader worden toegelicht, waarbij tevens acht wordt geslagen op de bijzondere verantwoordelijkheid die het EHRM en de Hoge Raad aan politici toedichten. Daaruit zal moeten blijken of de dreigende inbreuk op het legaliteitsbeginsel en de machtenscheiding, zoals die in de vorige paragraaf aan de orde is gesteld, door de rechter zelf kan worden afgewend.

\subsection{De drietrapsraket van de Hoge Raad}

Vanaf 2001 heeft de Hoge Raad een algemeen toetsingskader ontwikkeld voor de artikelen 137c en 137d Sr. Deze ontwikkeling is begonnen met een tweetal vormende arresten. ${ }^{65}$ Daarin werd, in navolging van Straatsburgse jurisprudentie, een zogeheten contextuele toetsing opgenomen. Deze toetsing is een uitwerking van het in artikel 10 lid 2 EVRM opgenomen en hierboven besproken noodzakelijksvereiste. Zoals gezegd, mag de nationale rechter de noodzaak van een beperking alleen aannemen als er sprake is van een pressing social need en als de beperking proportioneel is ten opzichte van het nagestreefde doel. Tevens geldt de eis van subsidiariteit: pas wanneer alle minder ingrijpende middelen zijn uitgeput, mag de rechter een beperking op grond van artikel 10 lid 2 EVRM toestaan. ${ }^{66}$

Wat direct opvalt aan de jurisprudentie die op basis van deze grondnormen tot stand is gekomen, is dat het EHRM bij het vaststellen van de noodzakelijkheid van een beperking een hoge drempel hanteert voor uitlatingen die zijn gedaan in het kader van een 'publiek' of 'maatschappelijk' debat. ${ }^{67}$ Deze gedachtegang is grofweg terug te voeren op twee uitspraken. De eerste betreft Handyside $v$. Verenigd Koninkrijk (1976), waarin het Hof de vrijheid van meningsuiting typeerde als 'one of the essential foundations of a democratic society'. Dit houdt volgens het Hof in dat een democratische samenleving niet alleen ideeën en informatievoorziening moet tolereren die gemeengoed zijn of niet als beledigend worden gezien, maar vooral ook ruimte moet bieden aan uitingen die een deel van de samenleving kunnen choqueren, beledigen of verontrusten. 'Those are the

65 HR 9 januari 2001, NJ 2001, 203; HR 14 januari 2003, NJ 2003, 261.

66 Nieuwenhuis, Over de grens van de vrijheid van meningsuiting (2015), 316-317.

67 Nieuwenhuis, Over de grens van de vrijheid van meningsuiting (2015), 308-309. Zie ook Janssens \& Nieuwenhuis, Uitingsdelicten (2011), 48-49. 
demands of pluralism, tolerance and broadmindedness without which there is no democratic society', aldus het Hof. ${ }^{68}$ Ten aanzien van gekozen volksvertegenwoordigers dient de rechter bij uitstek terughoudend te zijn, zo volgt uit de zaak Castells v. Spanje (1992): 'While freedom of expression is important for everybody, it is especically so for an elected representative of the people. He represents his electorate, draws attention to their preoccupations and defends their interests. Accordingly, interferences with the freedom of expression call for the closest scrutiny on the part of the court'. ${ }^{69}$

De Hoge Raad is de redeneertrant uit deze twee uitspraken allengs gaan overnemen waar het gaat om de toepassing van de artikelen 137c en 137d Sr, hetgeen leidde tot de ontwikkeling van het contextuele toetsingskader. De spraakmakende strafzaak tegen het Tweede Kamerlid Van Dijke uit 1998 vormde daarvoor de eerste aanzet. Aanleiding was een interview met Van Dijke in het weekblad Nieuwe Revue waarin hij onder meer had gezegd:

'Waarom zou stelen, bijvoorbeeld uitkeringen pikken van de overheid, minder erg zijn dan zondigen tegen het zevende gebod. Ja, waarom zou een praktiserend homoseksueel beter zijn dan een dief. ${ }^{, 70}$

De rechtbank was van mening dat Van Dijkes uitlatingen zonder meer beledigend waren en dat het feit dat hij deze uitlatingen had gedaan in het kader van zijn geloofsovertuiging dit niet anders maakte. Dat de verdachte volksvertegenwoordiger was werd hem door de rechtbank in het bijzonder aangerekend, omdat van een verdachte in die hoedanigheid 'verwacht mag worden dat hij rekening houdt met gevoelens en denkbeelden die in de samenleving aanwezig zijn'. ${ }^{71}$ Op een volksvertegenwoordiger rust, zo redeneerde de rechtbank, een grotere verantwoordelijkheid om op zijn woorden te letten dan op een gewone burger.

Van Dijke ging tegen de uitspraak in beroep bij het gerechtshof, dat in tegenstelling tot de rechtbank een uitgebreide contextuele toetsing op zijn uitspraken toepaste. Daarbij gebruikte het hof de volgende drie stappen. Allereerst werd bezien of de gewraakte uitlatingen op zichzelf, dat wil zeggen los van de context, als beledigend waren aan te merken. Daarvan was in dit geval sprake, omdat de (gelijk)waardigheid van homoseksuelen door de opmerkingen van Van Dijke werd miskend. ${ }^{72}$ Bij de volgende stap overwoog het hof of de context waarin de betreffende uitlatingen waren gedaan het beledigende karakter kon wegnemen. Met het oog daarop werd overwogen dat de uitlatingen van de verdachte in direct verband stonden met zijn geloofsovertuiging, hetgeen 
voldoende was om het beledigende karakter van de uitlatingen weg te nemen. ${ }^{73}$ Als derde en laatste stap ging het hof na of de uitlatingen ondanks de disculperende context in onnodig grievende vorm waren uitgedrukt. Omdat Van Dijke volgens het hof wat dit betreft binnen acceptabele grenzen was gebleven, kon uiteindelijk vrijspraak volgen. ${ }^{74}$

$\mathrm{Nu}$ kan tegen deze beslissing het bezwaar worden ingebracht dat het hof wel heel gemakkelijk genoegen nam met het subjectieve beroep van de verdachte op zijn geloofsopvatting. ${ }^{75}$ De Hoge Raad is zich kennelijk van dit euvel bewust geweest en heeft het in cassatie geprobeerd weg te nemen door te stellen dat de uitlatingen van Van Dijke 'kenbaar in direct verband stonden met de uiting van de geloofsopvatting [van de verdachte] en als zodanig voor hem van betekenis zijn in het maatschappelijk debat'. ${ }^{76}$ Met die laatste zinssnede heeft de Hoge Raad aangegeven dat een puur subjectief beroep op een geloofsovertuiging niet als een ontsnappingsroute voor strafbare groepsbelediging heeft te gelden. Of dat gelukt is door de uitlatingen aan het meer objectieve begrip 'maatschappelijk debat' op te hangen is zeer de vraag, nu er nog steeds een subjectief element ('voor hem') in de uitspraak aanwezig was.

In de jurisprudentie die op de zaak-Van Dijke volgde, is de contextuele toetsing in ieder geval verder uitgewerkt en verfijnd. Daarin is de vraag of er sprake is van een bijdrage aan het maatschappelijk debat niet langer subjectief benaderd maar als een objectief, door de rechter toetsbaar criterium gepresenteerd. In beginsel geldt dit ook voor de vraag of een uitlating onnodig grievend is; de derde stap in het toetsingsmodel. De rechter toetst daarbij enkel of de verdachte met de gekozen bewoordingen binnen de algemene fatsoensnormen is gebleven, waarmee dit onderdeel ziet op de vorm en niet op de inhoud van een uitlating. ${ }^{77}$ Voorts wordt de contextuele toetsing sinds 2011 ook toegepast op uitlatingen die vallen onder $137 \mathrm{~d} \mathrm{Sr},{ }^{78}$ hetgeen de beschermende werking van het model verder heeft uitgebreid.

Sackers stelt dan ook terecht dat de Hoge Raad met de introductie van het toetsingskader een extra waarborg tegen een te snel ingrijpen van de strafrechter

73 Hof Den Haag 9 juni 1999, AB 1999, 328.

74 Hof Den Haag 9 juni 1999, AB 1999, 328.

75 Zie in dit verband de kritiek van G. Molier, 'De vrijheid van meningsuiting: 'it's politics all the way down', in Mag ik dit zeggen? Beschouwingen over de vrijheid van meningsuiting, red. A. Ellian, G. Molier \& T. Zwart, (Den Haag: Boom Juridisch, 2013), 215.

76 HR 9 januari 2001, $A B$ 2001, 303.

77 Janssens \& Nieuwenhuis betwijfelen echter of dit criterium niet alsnog de deur openzet voor een inhoudelijke, dat wil zeggen subjectieve beoordeling van de gekozen bewoordingen. Zij geven als voorbeeld de uitlatingen 'God is het kwaad' of 'Jezus is een oplichter', welke voor de vrome christen ongetwijfeld nodeloos grievend zijn maar voor de meeste rechtsdeelnemers inmiddels niet langer als buitenproportioneel zullen worden ervaren. Bovendien roepen de auteurs op tot een terughoudende toepassing van dit criterium. Zie Janssens \& Nieuwenhuis, Uitingsdelicten (2011), 392.

78 Nieuwenhuis, Uitingsdelicten (2011), 52. Zie ook Rb. Amsterdam 23 juni 2011, LJN BQ 9001 (Wilders). 
heeft trachten te creëren. ${ }^{79}$ Op het punt van zowel de rechtszekerheid als de machtenscheiding kan dit dan ook een positieve uitwerking hebben, nu de rechter op basis van het criterium 'bijdrage aan het maatschappelijk debat' een stuk gemakkelijker uit politiek vaarwater kan wegsturen. Een belangrijk gevolg daarvan zou kunnen zijn dat het toetsingskader meer ruimte biedt voor het huldigen van controversiële standpunten en het aankaarten van problemen of kwesties die zien op bijvoorbeeld de maatschappelijke rol of positie van bepaalde (minderheids)groeperingen. Of het toetsingsmodel deze heilzame effecten in de praktijk daadwerkelijk heeft, valt echter ook te betwijfelen. Weliswaar is de grens van het toelaatbare danig opgeschoven, dit betekent nog niet dat die grens zelf duidelijker geworden is. Dit heeft er primair mee te maken dat de rechter nog steeds de lastige maar tegelijk cruciale afweging moet maken welke uitlatingen een 'bijdrage aan het maatschappelijk debat' leveren en welke 'onnodig grievend' zijn en daarmee ontoelaatbaar. Of de Hoge Raad de zorg over de invloed van de strafrechter op de publieke discussie kan wegnemen, blijft dan ook zeer de vraag.

\section{2. 'Onverdraagzaamheid' en de 'bijzondere verantwoordelijkheid' van politici}

De contextuele toetsing zoals voorgeschreven door de Hoge Raad lijkt op het eerste gezicht alleen maar voordelen te hebben. Zij biedt namelijk 1) bijzondere bescherming aan uitlatingen die dienstig zijn aan of onderdeel van een maatschappelijk debat, 2) op basis van criteria die tot op zekere hoogte objectief kunnen worden toegepast en 3) het toetsingskader strekt zich tevens uit over uitlatingen die vallen onder artikel 137d Sr. Tegelijkertijd moet niet worden vergeten dat het derde onderdeel van de drietrapsraket van de Hoge Raad, de onnodig grievendheidtoets, een essentiële rol speelt bij het inkleuren van de proportionaliteit. Dit betekent dat de afweging of een uitlating 'dienstig is aan een maatschappelijk debat' of dat deze in een 'onnodig grievende' vorm is gedaan, uiteindelijk door de rechter moet worden gemaakt. ${ }^{80}$ Anders gesteld: de meetlat waarlangs moet worden bepaald of een concrete uitlating valt binnen de context van het maatschappelijk debat óf niet, kan via jurisprudentiële weg worden ingevuld en dus ook worden aangepast, met als gevolg dat de reikwijdte van de bescherming van het ene op het andere moment kan wijzigen. Precies deze ontwikkeling lijkt zich te hebben voltrokken in nieuwe jurisprudentie van de Hoge Raad, waarin het begrip 'onnodig grievend' een nieuwe inkleuring heeft gekregen. Deze ingreep staat niet op zichzelf maar sluit aan op een nieuwe trend in de rechtspraak van het Europees hof waarbij de bestrijding van hate speech als een verderfelijke vorm van 'intolerantie' centraal staat. ${ }^{81}$ Beschouwingen over de vrijheid van meningsuiting, red. A. Ellian, G. Molier \& T. Zwart, (Den Haag: Boom Juridisch, 2013), 309-327.

80 Zie opnieuw Janssens \& Nieuwenhuis, Uitingsdelicten (2011), 111, 114.

81 Deze trend lijkt te zijn ingezet in een tweetal aanbevelingen van de Raad van Europa, waarin de verhouding tussen hate speech en de vrijheid van meningsuiting wordt gedefinieerd. Zie Council of Europe, Committee of Minister, Recommendations No. R(97) 20 on 'Hate Speech', 30 oktober 1997; Council of Europe, Committee of Minister, Declaration on freedom of political debate the media, 12 februari 2004. 
Een belangrijke, maatgevende uitspraak in deze ontwikkeling is Féret v. België (2009). ${ }^{82}$ In deze zaak moest het Europees hof toetsen of de Waalse politicus Daniel Féret terecht was veroordeeld voor het aanzetten tot discriminatie, haat en geweld. Het ging in die zaak om de verspreiding van politieke pamfletten waarin onder meer werd opgeroepen tot het weigeren van arbeidsplaatsen aan migranten uit islamitische landen en waarin asielzoekers als illegaal en dus crimineel' werden bestempeld. ${ }^{83}$ Het Europees hof gaf de Belgische rechter gelijk en stelde daarbij voorop dat volksvertegenwoordigers - in lijn met de Castellsuitspraak - weliswaar een extra groot belang hebben bij de vrijheid van meningsuiting, maar dat tegelijkertijd ook van hen mag worden verwacht dat zij nalaten om opmerkingen te maken die de intolerantie in de samenleving kunnen voeden. ${ }^{84}$ Met een nipte meerderheid van stemmen (vier tegen drie) voegde het EHRM met deze uitspraak een belangrijk gezichtspunt toe aan de toetsing van het criterium 'bijdrage aan het maatschappelijk debat'. Dit komt erop neer dat de noodzakelijkheid van een beperking van de vrijheid van meningsuiting bij politici minder snel wordt aangenomen vanwege hun bijzondere functie, behalve als het gaat om uitlatingen die getuigen van racisme, xenofobie en andere vormen van 'onverdraagzaamheid'. In die gevallen kan een beperking van de uitingsvrijheid juist eerder noodzakelijk worden geacht. ${ }^{85}$

Hoewel dit uitgangspunt vanwege de verdeeldheid van het Hof gerust controversieel kan worden genoemd, heeft de Hoge Raad zich bij het uitmaken van een strafzaak tegen de Amsterdamse politicus Felter in 2014 duidelijk door de nieuwe Féret-doctrine laten inspireren. ${ }^{86}$ Felter, kandidaat voor de gemeenteraadsverkiezingen, had zich tijdens en na afloop van een debat in De Rode Hoed op zijn zachtst gezegd negatief uitgelaten over homoseksuelen, waarvoor hij door het Openbaar Ministerie werd vervolgd. Zowel de rechtbank als het hof in Amsterdam spraken hem vrij, waarna de zaak bij de Hoge Raad terecht kwam. Dit oordeelde dat het hof blijk had gegeven van een onjuiste rechtsopvatting, omdat het de drie stappen uit het contextuele toetsingsmodel niet (volledig) had doorlopen. Om die reden moest de zaak opnieuw aan de feitenrechter worden voorgelegd. ${ }^{87}$ Hoewel de Hoge Raad het daarbij had kunnen laten, aangezien het toetsingsmodel op zich al voldoende aanknopingspunten bood voor de veroordeling van deze verdachte, achtte de hoogste rechter het noodzakelijk om aangaande de toepassing van het begrip 'onnodig grievend' het volgende op te merken:

'Bij de beoordeling van de vraag of een uitlating onnodig grievend is, dient, indien het gaat om een politicus in het kader van het publiek debat - het

82 EHRM 16 juli 2009, Féret v. België, appl.nr. 15615/07. Daarnaast kan worden gewezen op de zaak EHRM 6 juli 2006, Erbakan v. Turkije, appl.nr. 59405/00.

83 Noot bij het arrest Féret v. België (EHRM), Mediaforum 2009-10, 373-378.

84 EHRM 16 juli 2009, Féret v. België, appl.nr. 15615/07, r.o. 54.

85 Noot bij het arrest Féret v. België (EHRM), Mediaforum 2009-10, 376(r).

86 HR 16 december 2014, ELCI:NL:HR:2014:3583.

87 HR 16 december 2014, ELCI:NL:HR:2014:3583, par. 4.3-4.5. 
politieke debat daaronder begrepen - onder ogen te worden gezien, enerzijds het belang dat de betreffende politicus daadwerkelijk in staat moet zijn zaken van algemeen belang aan de orde te stellen, ook als zijn uitlatingen kunnen kwetsen choqueren of verontrusten, maar anderzijds ook de verantwoordelijkheid die de politicus in het publieke debat draagt om te voorkomen dat hij uitlatingen doet die strijdig zijn met de wet en de beginselen van de democratische rechtsstaat. Daarbij gaat het niet uitsluitend om uitlatingen die aanzetten tot haat of geweld of discriminatie maar ook om uitlatingen die aanzetten tot onverdraagzaamheid. 88

Uit deze passage volgt dat de Hoge Raad de tweeledige uitleg van het EHRM in de zaak-Féret in zijn eigen toetsingsmodel heeft willen integreren. Naast de Castellsdoctrine, die voor politici in beginsel een grotere vrijheid van meningsuiting reserveert, plaatst de Hoge Raad nu ook de lijn-Féret, die politici juist een grotere verantwoordelijkheid toedicht. Daarbij wordt het begrip onverdraagzaamheid omgevormd tot iets wat lijkt op een delict ('aanzetten tot onverdraagzaamheid') en gekoppeld aan de derde stap in het contextuele toetsingsmodel die ziet op de vorm van een uitlating (al dan niet 'onnodig grievend'). Vervolgens stelt de Hoge Raad dat dit nieuwe element in het toetsingsmodel uitsluitend betrekking heeft op politici, wat impliceert dat de vorm van een uitlating bij hen anders moet worden beoordeeld dan bij andere verdachten. Concreet betekent dit dat in alle 'normale' gevallen de rechter uitsluitend toetst of een beledigende, haatdragende of discriminerende uitlating die aan het maatschappelijk debat bijdraagt in onnodig grievende bewoordingen is uitgedrukt, terwijl bij de uitlatingen van een politicus ook moet worden bezien of deze aansporen tot 'onverdraagzaamheid' of anderszins strijdig zijn met 'de beginselen van de democratische rechtsstaat.'

Deze toevoeging lijkt in ieder geval twee belangrijke gevolgen te hebben. Ten eerste levert het een sterke relativering op van de hierboven getrokken conclusie dat het toetsingsmodel in beginsel extra ruimte biedt aan politieke en anderszins in het publieke debat gedane uitlatingen. De Castells-doctrine, die voor volksvertegenwoordigers (lees: politici) extra ruimte reserveert, wordt nu immers geflankeerd door een criterium dat aan de uitingsvrijheid van politici een aanvullende eis stelt. Met de introductie van deze eis is dan ook een principiële tegenstelling ontstaan binnen het toetsingsmodel; een tegenstelling die de rechter dus onmogelijk kan overbruggen. Het tweede belangrijke gevolg is dat de Hoge Raad de nogal verwarrende situatie in het leven heeft geroepen dat er bij de derde stap in het toetsingskader opnieuw inhoudelijk naar een uitspraak moet worden gekeken, namelijk of deze (inderdaad) strijdig is met de wet én de 'beginselen van de democratische rechtsstaat' (waaronder het beginsel van 'verdraagzaamheid'). Daarmee komt het toetsingsmodel in een cirkel terecht die de rechter in zowel de eerste als de laatste stap vraagt een inhoudelijk oordeel te geven over het beledigende, haatdragende dan wel discriminerende karakter van een uitlating. De toevoeging van de Hoge Raad leidt er dan ook toe dat het aspect 
van de vorm in de derde stap wordt omgezet in een nieuw, inhoudelijk beoordelingscriterium waaraan de uitlatingen van politici moeten voldoen om de proportionaliteitstoets te kunnen doorstaan.

Een belangrijk gevolg daarvan is weer dat de afweging tussen het belang van de vrijheid van meningsuiting enerzijds en de bescherming van de rechten van anderen anderzijds met dit nieuwe criterium nog onvoorspelbaarder is geworden dan hij al was. ${ }^{89}$ Om te kunnen bepalen of een inperking van de vrijheid van meningsuiting proportioneel is, moet de rechter nu immers toetsen aan begrippen die buitengewoon breed, vaag en multi-interpretabel zijn. Wat moet bijvoorbeeld worden verstaan onder het 'aanzetten tot onverdraagzaamheid' en welke andere principes kunnen naast dit beginsel onder de zeer algemene noemer 'beginselen van de democratische rechtsstaat' worden geschaard? Over het begrip verdraagzaamheid bestaat, blijkens de ontstane tegenstelling in de EHRMjurisprudentie, ${ }^{90}$ al nauwelijks een eenduidige, juridisch afgebakende definitie, laat staan dat rechters het in nieuwe strafzaken gemakkelijk eens zullen worden over welke andere uitgangspunten moeten gelden als de beginselen van ons staatsbestel. ${ }^{91}$ Maar zelfs al zouden zij het eens worden over de inhoud van deze beginselen, dan nog geldt dat de rechtszekerheid ongetwijfeld het eerste slachtoffer wordt van zulke ruim geformuleerde criteria.

Voor de hierboven besproken problematiek rondom de toepassing van de artikelen 137c en 137d Sr, die vooral ziet op een gebrek aan voorzienbaarheid van het strafrechtelijk optreden, biedt de jurisprudentie van de Hoge Raad dan ook geen oplossing. Sterker nog: Met het onduidelijke begrip 'aanzetten tot onverdraagzaamheid' in de hand lijkt het voor rechters juist gemakkelijker (en misschien ook wel verleidelijker) te zijn geworden om uitlatingen van politici die weliswaar vallen binnen de context van het maatschappelijk debat alsnog onder het bereik van de strafwet te brengen. ${ }^{92}$ Daarmee is de kans dat een politieke meningsuiting wordt gesanctioneerd op basis van het daarin vervatte standpunt

89 M. van Noorloos, 'De Hoge Raad over de vrijheid van meningsuiting van politici', Tijdschrift Praktijkwijzer Strafrecht afl. 12 (2015), 102.

90 De tegenstelling is het grootst bij een vergelijking tussen EHRM 7 december 1976, Handyside $v$. Verenigd Koninkrijk, appl.nr. 5493/72 en EHRM 16 juli 2009, Féret v. België, appl.nr. 15615/07.

91 Voor een interessante waaier aan visies op en duidingen van het tolerantiebegrip, zie M. ten Hooven (red.), De lege tolerantie: over vrijheid en vrijblijvendheid in Nederland (Amsterdam: Boom, 2002).

92 De recente uitspraak van het Gerechtshof Den Haag in de zaak-Wilders is hiervan een typisch voorbeeld. Nadat het hof de uitlating van Wilders over Marokkanen als op zichzelf beledigend had gekenschetst, werd beargumenteerd dat de uitlating vanwege de '(partij)politieke) context' evenwel een 'bijdrage aan het publiek debat' kon leveren. Dit mocht Wilders echter niet baten, want het hof kwam vervolgens weer tot de conclusie dat zijn uitlating 'onnodig grievend' is, onder meer omdat hij daarmee de 'verdraagzaamheid en [het] respect voor de gelijkwaardigheid van alle mensen', die gelden als 'het fundament van de democratische en pluriforme samenleving', had verloochend. En dat rekent het hof hem als politicus bijzonder aan. Wat het hof onder deze normen precies verstaat en waarom ze rechtvaardigen dat Wilders voor zijn bijdrage aan het debat toch moest worden veroordeeld, wordt in de uitspraak nauwelijks toegelicht. Zie Gerechtshof Den Haag, 4 september 2020, ECLI:NL:GHDHA:2020:1606, par. 8.4.3 en 11. 
ongetwijfeld toegenomen, met het aannemelijke gevolg dat volksvertegenwoordigers en de burgers die zij representeren zich minder snel zullen uitlaten over wat zij met betrekking tot bijvoorbeeld het migratie- en integratiebeleid in het algemeen belang achten (chilling effect). Op de vraag of de machtenscheiding onder druk staat als gevolg van de toepassing van de uitingsdelicten in 137c en 137d Sr kan dan ook positief worden geantwoord. De oorzaak hiervan ligt echter, in tegenstelling tot de indruk die in de Tweede Kamer met betrekking tot de zaakWilders is gewekt, niet primair bij de uitvoerende macht als wel bij de wetgever, die een te onduidelijk wettelijk kader heeft gecreëerd, en de rechter, die dit kader op zijn beurt alleen nog maar ingewikkelder heeft gemaakt en derhalve nog vatbaarder voor willekeurige interpretatie en toepassing. De parlementaire immuniteit, die ooit is bedacht om het politieke debat tegen zulke willekeur en machtsmisbruik te beschermen, kan dit nog maar ten dele compenseren, nu haar reikwijdte daarvoor - in het tijdperk van sociale media, YouTube en online streaming - simpelweg te beperkt is.

Overigens dreigt de Hoge Raad, blijkens de gekozen bewoordingen in het Felterarrest, in de dezelfde valkuil te trappen als Dworkin en Waldron (zie paragraaf 2.1) door de norm van verdraagzaamheid te verbinden met zowel de democratie als de rechtsstaat. Het is namelijk nogal tegenstrijdig om deze norm ook als democratisch te kenschetsen, terwijl zij juist wordt aangewend om de vrije meningsuiting in het democratische debat te begrenzen. Hooguit is deze norm, gezien haar beperkende werking, rechtsstatelijk van aard en heeft zij dus de bedoeling om de democratie 'te temmen'. Omdat de Hoge Raad deze nuance echter niet aanbrengt, ontstaat sterk de indruk dat iedereen die zich 'onverdraagzaam' uitlaat over een minderheidsgroepering ipso facto in strijd handelt met de democratie, wat een strengere norm voor politici, die immers het brandpunt van de representatieve democratie vormen, rechtvaardigt. ${ }^{93}$ Dat de Hoge Raad daarmee - al dan niet onbewust - een verkapt weerbare democratiemechanisme in het jurisprudentiële kader van de artikelen 137c en 137d Sr heeft ingelezen, is tegen de achtergrond van de wetsgeschiedenis, die daarvoor geen

93 Zie in dit verband een interessant redactioneel commentaar van Stefan Rummens in NJLP 1 (2011): S. Rummens, 'De vrije mening van politici', NJLP 1 (2011), 3-5. Rummens voert de 'conceptuele verwarring' die is ontstaan binnen de jurisprudentie van het Europees Hof terug op een dieperliggende politiek-theoretische tegenstelling tussen een proceduralistische en een militante visie op de democratie. Doordat deze tegengestelde visies volgens hem niet duidelijk van elkaar worden onderscheiden, en zoals ik tevens betoog, steevast in een adem worden genoemd, is het haast onmogelijk de fundamentele meningsverschillen over de vervolging van bijv. Geert Wilders goed te begrijpen. Evenwel maakt Rummens wat mij betreft dezelfde fout als Waldron en de Hoge Raad als hij stelt dat een middenweg tussen beide visies op de democratie tenminste zou moeten bestaan uit 'voldoende filters in het democratische proces', omdat deze kunnen voorkomen dat 'fundamentele democratische waarden' worden geschonden. Wat Rummens hier - volgens mij - bedoelt is dat bepaalde liberale of menselijke waarden niet geschonden mogen worden en om dat te bereiken moeten democratische besluiten worden 'gefilterd'. Daar is echter niets democratisch aan nu dit filteren de democratie niet bevordert of beschermt maar juist beperkt. Hij bepleit daarmee eerder een sterkere rechtsstaat als check op de democratie - een militante democratie dus. 
enkel concreet aanknopingspunt biedt, echter zeer bedenkelijk. ${ }^{94}$ Het is dan ook een interpretatie van de desbetreffende delicten waarmee de Hoge Raad de grens van zijn mandaat als toepasser en hooguit verfijner van de strafwet, ongetwijfeld heeft overschreden.

\section{Conclusie}

In dit artikel is de vraag onderzocht of de scheiding tussen de politiek en de rechterlijke macht onder druk komt te staan als gevolg van de toepassing van de strafbepalingen 137c en 137d Sr op uitspraken van politici. Deze vraag is opgeworpen naar aanleiding van zorgen in de Tweede Kamer over de mogelijke bemoeienis van de regering bij de totstandkoming en het verloop van de strafzaak tegen het Kamerlid Geert Wilders. Toegespitst op die bewuste strafzaak is tevens de vraag opgeworpen of de omstandigheid dat de regering de grenzen van zijn staatsrechtelijke bevoegdheid mogelijk te buiten is gegaan niet deels is ingegeven door een te vaag wettelijk en te complex jurisprudentieel kader rondom de betreffende uitingsdelicten en, in het verlengde daarvan, of de Tweede Kamer zijn kritiek dus wel op de juiste staatsmacht heeft gericht. Is het, met andere woorden, niet zozeer de uitvoerende als wel de wetgevende en rechtsprekende macht waarover de Tweede Kamer zich zorgen zou moeten maken en zou zij haar kritische hand daarom niet deels in eigen boezem moeten steken?

Om hierop een antwoord te kunnen formuleren is allereerst kritisch gekeken naar de relatie tussen de representatieve democratie en de vrijheid van meningsuiting en ook welke rol de strafrechter zou moeten spelen bij de afbakening daarvan. Daarbij is vooreerst stilgestaan bij de betekenis van een vrij publiek debat in een representatieve democratie. Hieruit volgde dat de mogelijkheid van burgers om zich (al dan niet via vertegenwoordiging) in vrijheid met de openbare discussie te bemoeien niet zozeer een onderdeel van de democratie is als wel de legitimerende grondslag ervan. Dit betekent dat de vrijheid van meningsuiting niet alleen een belangrijk (individueel) recht is, zoals zoveel andere belangrijke rechten, maar dat deze vrijheid vanwege zijn specifieke belang voor het functioneren en de legitimiteit van de democratie een zeker constitutioneel primaat zou moeten

94 De Nederlandse (grond)wetgever heeft, in tegenstelling tot bijvoorbeeld de Duitse, de constitutionele doctrine van weerbare democratie nooit expliciet gekoppeld aan de doelstellingen van de artikelen 137c en 137d Sr. Ten aanzien van art. 2:20 BW, dat voorziet in het verenigingsverbod, maakte de wetgever een dergelijke koppeling wel. Bij de invulling van het voor dit artikel cruciale uitgangspunt 'strijd met de openbare orde' gaf de wetgever aan dat dit ook handelingen omvat die 'inbreuk maken op de algemeen aanvaarde grondvesten van ons rechtsstelsel', waaronder 'aantasting van menselijke waardigheid'. Deze norm valt vervolgens weer uiteen in 'rassendiscriminatie en andere verboden discriminatie' en 'uitlatingen zoals het aanzetten tot haat en uitingen die verboden discriminatie inhouden'. Zie Kamerstukken II 1981/82, 17 476, nr. 5, 3. Het heeft er alle schijn van dat de Hoge Raad met het strafrechtelijke onverdraagzaamheidscriterium bij de bovengenoemde interpretatie van art. 2:20 BW probeert aan te sluiten en daarmee ook bij de daarin vervatte weerbare democratie-gedachte. Voor deze, op het eerste gezicht logische trend, is echter geen basis te vinden te vinden in de wetsgeschiedenis van de artikelen $137 \mathrm{c}$ en $137 \mathrm{~d}$ Sr. 
genieten. De vrijheid van meningsuiting in de publieke discussie is, met andere woorden, de constitutie van de democratische constitutie. Vervolgens is uiteengezet dat deze visie op de democratie, die is ontleend aan Eric Heinze, aansluit op de grondwettelijk verankerde parlementaire immuniteit: een regeling die de politieke discussie in het parlement volledig van strafrechtelijke interventie afschermt.

Omdat de parlementaire immuniteit in Nederland echter beperkt is in zijn reikwijdte maar de politieke discussie zich dikwijls buiten de muren van het parlement voltrekt, is de aandacht verschoven naar het 'gewone' recht op vrijheid van meningsuiting (art. $7 \mathrm{Gw}$ en art. 10 EVRM) en de invloed die de strafrechter heeft op de afbakening daarvan op basis van de strafwet. Daaruit is naar voren gekomen dat de artikelen 137c en 137d Sr op gespannen voet kunnen staan met het legaliteitsbeginsel en in het bijzonder het lex certa-vereiste, omdat de reikwijdte van deze bepalingen op een aantal fronten onduidelijk is. Dit heeft in de eerste plaats te maken met de formulering die de wetgever voor enkele centrale bestanddelen van deze delicten heeft gekozen maar ook, in de tweede plaats, met het feit dat rechter mede als gevolg daarvan behoorlijk wat interpretatieruimte heeft. Omdat dit kan leiden tot rechtsonzekerheid, die zich in terughoudendheid of zelfcensuur kan uiten (chilling effect), is de vraag opgeworpen of de rechterlijke toepassing van de artikelen 137c en 137d Sr het vrije publieke debat niet te veel in de weg zit en daarmee de scheiding tussen de politiek en de rechtspraak onder druk zet.

In de laatste paragraaf is nagegaan of de jurisprudentie van het EHRM, op basis waarvan de Hoge Raad sinds het begin van deze eeuw een zogeheten contextuele toetsing toepast, deze zorg kan wegnemen. Een essentieel onderdeel van deze toetsing is namelijk de vraag of een in beginsel strafbare uitlating 'dienstig is aan het maatschappelijk debat' en om die reden toch moet worden toegestaan. Op het eerste gezicht lijkt deze benadering een positief effect op de rechtszekerheid te hebben, omdat zij meer ruimte biedt aan de vrije uitwisseling van afwijkende of controversiële standpunten. Bovendien stelt het toetsingsmodel de rechter in staat om zich buiten gevoelige politieke controverses te houden, wat met het oog op de machtenscheiding is toe te juichen. Toch is de gedachte dat het toetsingsmodel de twee voornaamste punten van zorg, namelijk de rechtszekerheid en de machtenscheiding, kan wegnemen, niet juist gebleken, omdat dit model op het punt van de proportionaliteit recentelijk weer is aangepast. Geïnspireerd door een uitspraak van het EHRM uit 2009 hanteert de Hoge Raad tegenwoordig een nieuw criterium voor de toelaatbaarheid van uitlatingen van politici in het maatschappelijk debat; het zogeheten onverdraagzaamheidscriterium. Omdat dit een ondergedefinieerd en daarmee multi-interpretabel begrip is dat niet langer uitsluitend ziet op de vorm maar ook op de inhoud van een uitlating, is de waarborg voor een duidelijk afgebakend en relatief vrij publiek debat die het contextuele toetsingsmodel aanvankelijk leek te bieden, weer op losse schroeven gezet. 
Het centrale probleem van een te grote rechtsonzekerheid en het chilling effect dat daarvan het aannemelijke gevolg is, blijft dan ook onopgelost. Sterker nog. Op basis van de nieuwe jurisprudentie van de Hoge Raad is de behoefte aan duidelijke grenzen en sterke waarborgen voor een vrije uitwisseling van politieke standpunten, nog groter geworden. Bij de vraag tegen wie deze waarborgen voornamelijk moeten zijn gericht, dient niet slechts de rol van de uitvoerende macht ter discussie te staan maar zal tevens kritisch naar de invloed van de rechterlijke macht moeten worden gekeken. In tegenstelling tot wat vaak wordt aangenomen, namelijk dat de rechterlijke macht de the least dangerous branch binnen de trias politica is, ${ }^{95}$ valt de invloed die de strafrechter via jurisprudentie op de reikwijdte van de vrijheid van meningsuiting kan uitoefenen niet te onderschatten. De zorgen in de Tweede Kamer over de dubieuze totstandkoming van de zaak-Wilders zijn dan ook niet onterecht, maar richten zich wel op de verkeerde staatsmacht. De vage wettelijke normen en de minstens zo onduidelijke jurisprudentiële uitwerking daarvan kan in dit verband een gevaarlijke cocktail zijn die tot de oprekking dan wel het misbruik van bevoegdheden kan leiden. Naast het kritisch volgen van de uitvoerende macht zal daarom ook de rechterlijke macht enigszins beteugeld moeten worden.

Het zou daarom op zijn plaats als de Tweede Kamer, in plaats van passief af te wachten, het initiatief neemt tot een grondige herziening van de artikelen 137c en $137 \mathrm{~d}$ Sr. ${ }^{96}$ Daarbij zou - met het probleem van de tanende rechtszekerheid in het achterhoofd - in elk geval een scherper onderscheid gemaakt moeten worden tussen beledigende of discriminatoire opmerkingen enerzijds en directe aansporingen tot haat en geweld anderzijds, waarbij uitsluitend de laatste categorie voorwerp van het strafrecht zou moeten zijn. Voorts zou de parlementaire immuniteit kunnen worden uitgebreid, zodat dit beginsel zijn oorspronkelijke functie, namelijk het beschermen van het politieke debat tegen ongewenste inmenging van de andere staatsmachten, weer adequaat kan vervullen. ${ }^{97}$ Met deze veranderingen bewijst men geen bijzondere dienst aan 'populisten' of 'radicalen', zoals wel eens wordt tegengeworpen, maar wordt veeleer de legitimiteit en het functioneren van de democratie als zodanig bevorderd. Evenmin houden de genoemde voorstellen een verslapping van de rechtsstaat in. Sterker nog: door de eisen van het legaliteitsbeginsel, zoals duidelijkheid en voorzienbaarheid, serieus te nemen, kan de rechtsstaat alleen maar worden versterkt. En wat betreft het bezwaar dat een verruiming van de uitingsvrijheid alleen maar leidt tot meer polarisatie en stemmingmakerij ten

95 A. Hamilton, J. Madison \& J. Jay, The Federalist papers (Oxford: Oxford University Press, 2008), 380 (no. 78).

96 Zie bijvoorbeeld het wijzigingsvoorstel van het Kamerlid Van Klaveren uit 2014 om art. 137c in zijn geheel te schrappen en art. 137d te beperken tot het aanzetten tot geweld. Kamerstukken II, 2014-15, 34501. Voor een genuanceerder pleidooi, waarbij specifiek wordt gepleit voor het schrappen van groepsbelediging op grond van religie, zie G. Molier, 'Over de Vrijheid van Meningsuiting en Groepsbelediging wegens Religie’, Civis Mundi (2009), 155-167.

97 Zie met name Nehmelman, 'Spreken is zilver, maar wie bepaalt wanneer zwijgen goud is' (2011); Peters, 'Immuniteit ook buiten het parlementair debat' (2010). 
Jip Stam

aanzien van minderheden, zou de wetgever het volgende nog eens moeten overwegen: 'Het strafrecht [...] kan slechts in geringe mate bijdragen tot het oplossen van maatschappelijke spanningen. Toepassen ervan kan zelfs leiden tot verscherping van het conflict'. ${ }^{98}$ 